\title{
Interventions to modify sexual risk behaviours for preventing HIV in homeless youth (Review)
}

\author{
Naranbhai V, Abdool Karim Q, Meyer-Weitz A
}

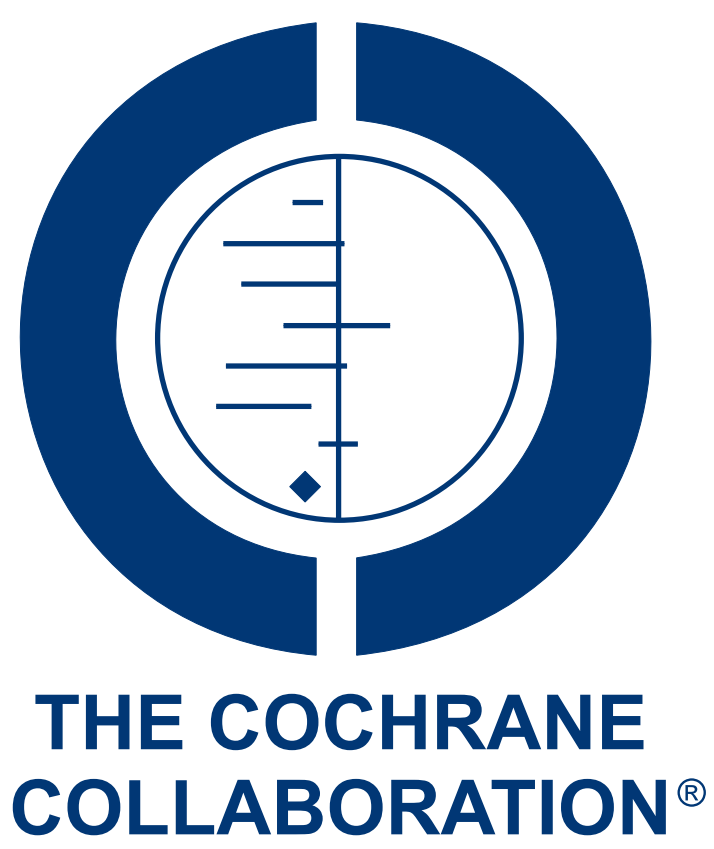

This is a reprint of a Cochrane review, prepared and maintained by The Cochrane Collaboration and published in The Cochrane Library 2011, Issue 1

http://www.thecochranelibrary.com

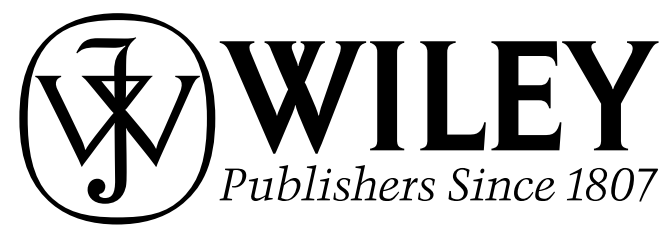

Interventions to modify sexual risk behaviours for preventing HIV in homeless youth (Review)

Copyright (C) 201 I The Cochrane Collaboration. Published by John Wiley \& Sons, Ltd. 
TABLE OF CONTENTS

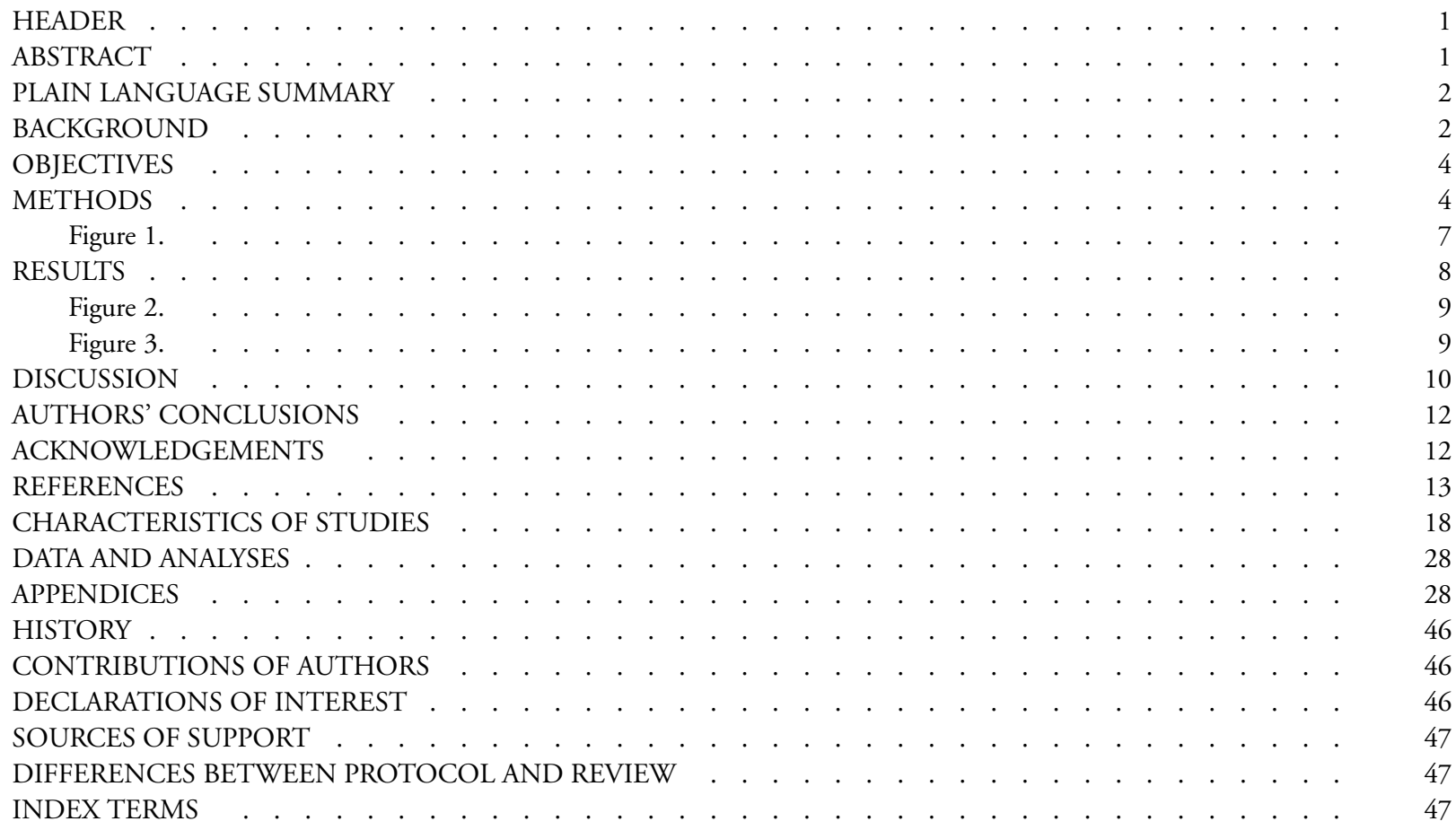

Interventions to modify sexual risk behaviours for preventing HIV in homeless youth (Review)

Copyright $\odot$ 20II The Cochrane Collaboration. Published by John Wiley \& Sons, Ltd. 


\title{
Interventions to modify sexual risk behaviours for preventing HIV in homeless youth
}

\author{
Vivek Naranbhai ${ }^{1}$, Quarraisha Abdool Karim ${ }^{1}$, Anna Meyer-Weitz ${ }^{2}$ \\ ${ }^{1}$ Centre for the AIDS Programme of Research in South Africa, Doris Duke Medical Research Institute, Durban, South Africa. ${ }^{2}$ School \\ of Psychology, Howard College, University of KwaZulu-Natal, Durban, South Africa \\ Contact address: Vivek Naranbhai, Centre for the AIDS Programme of Research in South Africa, Doris Duke Medical Research \\ Institute, Nelson R Mandela School of Medicine, University of KwaZulu Natal, Congella, Durban, KwaZuluNatal, 4001, South Africa. \\ vnaranbhai@gmail.com.
}

Editorial group: Cochrane HIV/AIDS Group.

Publication status and date: New, published in Issue 1, 2011.

Review content assessed as up-to-date: 16 June 2010.

Citation: Naranbhai V, Abdool Karim Q, Meyer-Weitz A. Interventions to modify sexual risk behaviours for preventing HIV in homeless youth. Cochrane Database of Systematic Reviews 2011, Issue 1. Art. No.: CD007501. DOI: 10.1002/14651858.CD007501.pub2.

Copyright (C) 2011 The Cochrane Collaboration. Published by John Wiley \& Sons, Ltd.

\section{A B S T R A C T}

\section{Background}

Homeless youth are at high risk for HIV infection as a consequence of risky sexual behaviour. Interventions for homeless youth are challenging. Assessment of the effectiveness of interventions to modify sexual risk behaviours for preventing HIV in homeless youth is needed.

\section{Objectives}

To evaluate and summarize the effectiveness of interventions for modifying sexual risk behaviours and preventing transmission of HIV among homeless youth.

\section{Search methods}

We searched electronic databases (CENTRAL, MEDLINE, EMBASE, AIDSearch, Gateway, PsycInfo, LILACS), reference lists of eligible articles, international health agency publication lists, and clinical trial registries. The search was updated January 2010. We contacted authors of published reports and other key role players.

\section{Selection criteria}

Randomised studies of interventions to modify sexual risk behaviour (biological, self-reporting of sexual-risk behaviour or healthseeking behaviour) in homeless youth (12-24 years).

\section{Data collection and analysis}

Data from eligible studies were extracted by two reviewers. We assessed risk of bias per the Cochrane Collaborations tool. None of the eligible studies reported any primary biological outcomes for this review. Reports of self-reporting sexual risk behaviour outcomes varied across studies precluding calculation of summary measures of effect; we present the outcomes descriptively for each study. We contacted authors for missing or ambiguous data. 


\section{Main results}

We identified three eligible studies after screening a total of 255 unique records. All three were performed in the United States of America and recruited substance-abusing male and female adolescents (total $\mathrm{N}=615$ ) through homeless shelters into randomised controlled trials of independent and non-overlapping behavioural interventions. The three trials differed in theoretical background, delivery method, dosage (number of sessions,) content and outcome assessments. Overall, the variability in delivery and outcomes precluded estimation of summary of effect measures. We assessed the risk of bias to be high for each of the studies. Whilst some effect of the interventions on outcome measures were reported, heterogeneity and lack of robustness in these studies necessitate caution in interpreting the effectiveness of these interventions.

\section{Authors' conclusions}

The body of evidence does not permit conclusions on the impact of interventions to modify sexual risk behaviour in homeless youth; more research is required. While the psychosocial and contextual factors that fuel sexual risk behaviours among homeless youth challenge stringent methodologies of RCT's, novel ways for program delivery and trial retention are in need of development. Future trials should comply with rigorous methodology in design, delivery, outcome measurement and reporting.

\section{PLAIN LANGUAGESUMMARY}

\section{Ways to reduce risky sexual behaviour in homeless youth to prevent HIV}

There have been a limited number of rigorously conducted interventions to modify the sexual behaviour of homeless youth 12-24 years of age to prevent them from acquiring HIV. More research is required to identify effective strategies for this population. In this review, we systematically searched published and unpublished accounts of interventions that had been rigorously tested. We found three eligible independently conducted randomised controlled trials testing three different interventions. All three were conducted in the United States, amongst a total of 615 homeless, male and female youth. Due to the varied delivery of interventions, outcome measurement and reporting, we were unable to aggregate outcomes to estimate summary of effect measures. The significant risk of bias associated with the three included studies and their heterogeneity necessitate caution in interpreting the effectiveness of interventions to modify sexual risk behaviour for preventing HIV in homeless youth. While studies among homeless youth are highly challenging, future trials should comply with rigorous methodology in design, delivery, outcome measurement and reporting as well as consider the changing facets of homeless youth when designing HIV prevention tools.

\section{B A C K G R U N D}

Although youth is generally considered the healthiest phase of life, it is also a time of exploration and experimentation, with sexual identity and sexual practices and behaviours being major areas of development and change. Youth (aged 15-24 years) comprise about $18 \%$ (1.2 billion) of the global population of around 6.7 billion people (United Nations 2007). The unique biopsychosocial changes associated with this age group result in a disproportionate risk of HIV infection. Youth, therefore, are at the centre of the human immunodeficiency virus (HIV) pandemic (Doyle AM 2010; Ross 2006; ). But while estimates of the HIV burden of disease in adults (15-49 years) are routinely made, it is more difficult to gauge trends in the HIV disease burden amongst youth due to legal, ethical and moral constraints.

One of the most vulnerable groups is homeless youth, many of whom are forced by circumstance to engage in a variety of risky behaviours and who often are least likely to seek and/or have access to HIV prevention counselling, testing, and care. Unique strategies and interventions to reduce HIV acquisition sexually and through recreational drug use in this vulnerable group is necessary.

The focus of this review is to evaluate and summarize the effectiveness of interventions for preventing HIV by modifying sexual risk behaviours in homeless youth.

\section{Definition of terms}

The terms "youth," "adolescent/teenager," and "young adult" are often used interchangeably but at the same time are context and culture specific. Since 1985 (International Youth year), the United Nations has referred to people between the ages of 13 and 19 as teenagers and between the ages of 20 and 24 years as young 
adults; youth are defined as being between 15 and 24 years of age. It is estimated that in 2004, half of all HIV infections occurred in youth, and about $98 \%$ of the 10 million youth living with HIV/AIDS worldwide were in middle- or low-income countries (UNAIDS 2004). For the purposes of this review, we adopted a definition of youth being between the ages of 12 and 24 years (inclusive).

The term "homeless youth" refers to a wide variety of young people (i.e., runaway, throwaway, unaccompanied, street, and systems youth). Various countries have developed their own definitions of "homelessness" among youth. These are usually linked to the reason for their homelessness, with youth often emphasizing the throwaway and parents the runaway justification (Hammer 2002). A runaway is a youth who is away from home without the permission of parents or guardians; a throwaway is a young person who was asked to leave home by either parents/guardians or adults in the household (Hammer 2002). Girls seem more likely to be runaways (Hammer 2002) because of sexual abuse (Cauce 2000) while boys are more likely to be throwaways, possibly because of a greater likelihood of deviant behaviour (Moore 2006).

The term "street youth" can refer to homeless youth who live in high-risk, non-traditional places, such as under bridges, in abandoned buildings, and on the street, or to those whose lives are focused on the street (i.e., youth spending most of their time on the street and fending for themselves) but return to their homes on a regular basis. It should be noted that reference to the word "street" when discussing homeless youth is considered derogative by some investigators (Panter-Brick 2002). Street youth can be defined further in terms of these contexts:

- Street-living - youth who ran away from their families and live alone on the streets

- Street-working - youth who spend most of their time on the streets and fend for themselves but return home on a regular basis

- Street-family - youth who live on the streets with other (unrelated) street youth as a group

In addition, many street youth may be youth who have no family as a result of AIDS-related deaths amongst parents or other family members. This population of street youth is of growing importance in areas of high HIV prevalence.

Systems youth on the other hand are considered to be linked to government systems, such as juvenile justice or foster care, and are homeless due to abuse, neglect, or family incarceration or homelessness (Moore 2006). When a systems youth becomes homeless, it is often because they have run away from a home placement or because the placement failed to provide a stable living environment (Moore 2006). In addition, a common reason for a youth becoming homeless in the USA is ageing out of the youth foster care system.

Against this background, it is clear that homeless youth are a heterogenous group with unique contexts and needs. The hidden and transient nature of homeless youth make it difficult to estimate their numbers (Raleigh-DuRoff 2004), primarily, among other reasons because service providers and concerned adults attempt to "protect" youth from police and social services (Kidd 2004; Taylor 2004). UNICEF (2004) estimates that globally, there are about 100 million children who live on the street either all or part of the year. In the United States, it is estimated that about 1.5 to 2 million youths per year are homeless or have run away from home (Moore 2006). These estimates likely underestimate the number of youths who are homeless in a broader definition inclusive of orphans and vulnerable children (OVC) in contexts of poverty, war, famine, and HIV/AIDS. Crucially, there is a new and large cohort of homeless children and youth that have emerged as a result of premature death of parents, aunts, and uncles due to AIDS. This growing population is, by definition, coincident with the greatest population-level HIV risk in sub-Saharan Africa, Eastern Europe and South-East Asia. In 2008, roughly 18 million children (aged less than 18 years) had been orphaned by AIDS in sub-Saharan Africa alone (UNAIDS 2009), but the proportion who end up on the streets is not known. Homeless youth urgently and desperately need interventions not only targeting HIV risk reduction but also addressing gaps in social safety nets.

\section{Why it is important that interventions in this population be} reviewed

Homeless youth are highly vulnerable to HIV acquisition and transmission regardless of whether they live in a country with a focussed or a generalized epidemic due to their lives of heightened personal and social risk, which is often marked by violence, victimisation and human rights abuses (Boivin 2005; Greene 1997; MacLean 1999; Ramphele 1997; Ribeiro 2001). As a group, they lack the economic, social and emotional resources to provide for their basic needs, such as adequate sleep, clothing, shelter, and nutrition, which has dire consequences for their physical and emotional health (Van Wormer 2003). Studies have indicated that homeless youth have significant health risks related to sexual behaviour and substance use, both of which are linked to increased risk for HIV/AIDS and other STIs (Anarfi 1997; Baybuga 2004; de Carvalho 2006; Richter 1995; Walters 1999). In a review of 52 studies of the health of street youth in industrialized countries, these youth had higher rates of hepatitis B, C, and HIV than their non-street peers (Boivin 2005). Homeless youth, therefore, are of particular importance as a population at high risk for acquiring HIV infection.

The behaviours of youth are influenced by a range of factors including individual knowledge and attitudes; relationships with parents, caregivers, and peers; academic/school performance; socioe- 
conomic and environmental contexts; and access to health services. It is generally understood that the majority of youth are sexually active, do not have monogamous sexual relationships, and do not use condoms consistently, as is reflected in the increasing prevalence of HIV among youth worldwide (United Nations 2007). Risk behaviours among youth are often understood in terms of risk clustering, as different risk behaviours occur simultaneously, such as substance use and unprotected sex and sometimes delinquency. These behaviours also seem to have common determinants, meaning that they are affected by the same risk and protective factors (UNAIDS 2004).

Knowledge of sexuality (Gatu 2000; Richter 1995) and HIV/ AIDS among homeless youth is generally inadequate and not translated into preventive behaviours (Baybuga 2004; Bernier 1995; Gatu 2000; Robinson 2001; Snell 2002). Homeless youth are highly vulnerable to engaging in unprotected survival sex to meet their basic needs and/or feed a drug habit (Bernier 1995; Walters 1999) and are subject to rape (Swart-Kruger 1997). Because of their psychosocial and contextual environments, they are also highly likely to have multiple sexual partners (de Carvalho 2006; Haley 2004; Poulin 2001; Richter 1995; Roy 2000; Swart-Kruger 1997; van den Hoek 1997). Most are poorly equipped to combat sexual threats, as reported in an ongoing study of Montreal street youth, where only $13.2 \%$ of participants reported always using condoms during vaginal intercourse, and only $32.4 \%$ reported always using condoms during anal intercourse (Roy 2000). Homeless youth are more likely to engage in self-destructive behaviours, including suicide attempts, substance abuse (especially alcohol) and injecting drug use, compared to other youth (Rew 2001; Ringwalt 1998; Roy 2004). Suicide and drug overdose were reported to be two primary observed causes of mortality among homeless youth in a Canadian study (Roy 2004). The engagement in self-destructive behaviours is linked to psychological triggers, such as post-traumatic stress disorder (Cauce 2000), low self-esteem, and feelings of loneliness and hopelessness (Boivin 2005). These factors in turn accelerate and perpetuate the cycle of HIV vulnerability. In addition to traditional risk factors for HIV acquisition such as injection drug use, sharing needles, sexually transmitted infections or lack of condom use, having no place to live or being an orphan are independently associated with higher HIV prevalence in street youth (Kissin 2007, Robbins 2010).

Because they are marginalized and underserved, homeless youth do not have adequate access to social and health services, including health education (Baybuga 2004; Snell 2002). Thus, their HIV risk is not only related to their sexual practices, but are also linked to various predisposing and enabling factors that emerge from their psychosocial and contextual vulnerabilities (Lambert 2005).

In response to the need to address HIV/AIDS prevention worldwide, most countries have embarked on intensive mass media-, community-, and group-level interventions and the introduction of widespread antiretroviral treatment programmes (UNAIDS
2007). Randomised controlled trials undertaken in various countries have shown a reduction of high-risk sexual practices by youth who have taken part in behavioural interventions (DiClemente 1995; Kegeles 1996; Ross 2006; Underhill 2008).

Interventions directed specifically at modifying the sexual risk behaviours of homeless youth have unique challenges. Implementing workable and practical programmes for heterogeneous mobile populations in non-health care settings are difficult. Furthermore, for members of a group in which social and economic indigence may make it difficult to assert their sexual rights, HIV prevention messages could be viewed as irrelevant. Peer education and community-based interventions have been implemented to reduce HIV risk among homeless youth (Rotheram-Borus 1993; Rotheram-Borus 1997; Rotheram-Borus 1999). It has been argued that the ability of the programme to respond to the needs of youth stems from creative service approaches in which youth are involved in program design and in delivering the programme near where youths gather (Tenner 1998). Participatory and tailored interventions seem to be effective in meeting the diverse needs of marginalized youth (Tenner 1998).

This review will identify and allow lessons learned from effective interventions to guide the development and implementation of future HIV-risk reduction, behavioural modification interventions for homeless youth.

\section{O B J E C T I VES}

To evaluate and summarize the effectiveness of interventions for modifying sexual risk behaviours and preventing transmission of HIV/AIDS among homeless youth

\section{METHODS}

\section{Criteria for considering studies for this review}

\section{Types of studies}

Randomised controlled trials that have evaluated the behavioural effects and, where possible, the biological outcomes (e.g., STIs and HIV infection) of interventions for HIV prevention in homeless youth were included.

\section{Types of participants}

For the purposes of this review we included all homeless persons between the ages of 12-24 years (inclusive) regardless of HIV status, location, reason for homelessness, or gender. This definition is 
inclusive of homeless young people/adults, adolescents/teenagers and youth.

A homeless youth is a person who lacks a fixed, regular, and adequate nighttime residence; or is an individual who has a primary nighttime residence that is:

a. a supervised publicly or privately operated shelter designed to provide temporary living accommodations (including welfare hotels, congregate shelters, and transitional housing for the mentally ill);

b. an institution that provides a temporary residence for individuals intended to be institutionalised; or

c. a public or private place not designed for, or ordinarily used as, a regular sleeping accommodation for human beings (US Code Title 42).

Interventions amongst systems and street youth (see Background) were encompassed by the terms "homeless", "runaway" or "throwaway" and were potentially eligible for review.

\section{Types of interventions}

Any type of intervention including behavioural, social, policy, structural, or other interventions explicitly aimed at reducing sexual risk behaviour in homeless youth was included. Interventions delivered to individuals, small groups, or entire communities were eligible. Mantell has described the components an intervention should have to be termed a behavioural, social, policy, or structural intervention (Mantell 1997).

An intervention has a behavioural component if it aims to change individual behaviour without an explicit attempt to change peer or social norms that may influence a person's behaviour. It tends to emphasize individual and small-group approaches and includes psychosocial/cognitive interventions. Examples include one-onone interventions (e.g., HIV counselling and testing, notification assistance, support, peer interventions, role plays, tabling, AIDS hotline, HIV prevention technology); single event interventions (e.g., theatre, drama, video presentation, home risk-reduction parties), and multi-session interventions (e.g., skills-building and problem-solving workshops, training programs).

An intervention has a social component if it aims to change individual behaviour by explicitly attempting to change peer or social norms that may influence a person's behaviour. Examples include outreach interventions, engaging opinion leaders as educators, community mobilization, ethnographic interventions, small media-based interventions (e.g., using videos, brochures, pamphlets, newsletters, posters, and other print material), mass media-based interventions (e.g., using television, radio, films, talkshows, news casts, soaps, videos, music, posters, billboards, and public service announcements), community-based interventions using existing family networks/creating new social networks.

An intervention has a policy component if it aims to change individual behaviour or peer/social norms or structures that may influence a person's behaviour through administrative or legal de- cisions. Examples include mandatory HIV/AIDS education in all schools within a district.

An intervention has a structural component if it aims to change individual behaviour by making changes in people's environment. Examples include providing condom dispensers in bars and accompanying girls home from school to ensure their safety. Interventions may contain any or a combination of these components. These mixed interventions will be reported as such.

\section{Types of outcome measures}

Outcome measures based on the indicators for monitoring and evaluating national HIVIAIDS prevention programmes for young people (WHO 2004) were used.

- Primary outcomes: HIV infection, STI infection or pregnancy

- Secondary outcomes: self-reported abstinence or intentions regarding abstinence, condom use, unprotected intercourse, refusal of intercourse with no condom, frequency of consensual intercourse, frequency of non-consensual intercourse, type of intercourse (i.e., oral, vaginal, insertive-anal, receptive-anal), type of partner (i.e., same-gender, different gender), number of partners, mutual monogamy, intercourse while intoxicated

- Tertiary outcomes: visiting STI clinic, receiving pre-test counselling, taking an HIV test, receiving post-test counselling

We also included composite outcomes that included any of the above.

\section{Search methods for identification of studies}

\section{Electronic searches}

The following electronic databases were searched for RCTs for the period 1981 to December 2010 in two phases (Initial search: $1 \mathrm{Au}$ gust 2008, updated on 13 January 2010): MEDLINE (Appendix 5); EMBASE (Appendix 3); AIDSearch (Appendix 1); PsycInfo (Appendix 6) and LILACS (Appendix 7). The Cochrane Database of Systematic Reviews, Database of Abstracts of Reviews of Effectiveness and the Cochrane Central Register of Controlled Trials (CENTRAL, Appendix 2) in The Cochrane Library were also searched through January 2010.

We formulated comprehensive and exhaustive search strategies (Appendices) in an attempt to identify all relevant studies regardless of language or publication status (i.e., published, unpublished, in press, and in progress). Full details of the Cochrane HIV/AIDS Review Group methods and the journals handsearched are published on Collaborative Review Groups in the Cochrane Library. We used the RCT search strategy developed by The Cochrane Collaboration and detailed in the Cochrane Reviewers' handbook in combination with terms specific to "sexual risk" AND "behaviour" AND "homeless" AND "HIV" AND "youth"; the full search strategies are shown in Appendices. 


\section{Other:}

\section{Grey Literature}

The abstracts of relevant conferences, including the International Conferences on AIDS and the Conference on Retroviruses and Opportunistic Infections, as indexed by AIDSearch and/or Gateway, were reviewed. The publication websites of the World Health Organization, UNAIDS, CDC, and UNICEF were checked for references to technical reports or similar items that may relate to this topic and the reference lists of technical reports from UNAIDS were also searched.

\section{Reference Lists}

The search strategy was iterative, in that references of eligible studies were searched for additional references. Existing meta-analyses were reviewed and the reference lists checked for further articles. The reference lists of all review and primary publications identified were searched.

\section{Correspondence}

Researchers involved in HIV prevention were contacted for published and unpublished data and relevant information. Authors of potentially eligible trials were contacted for additional information, as appropriate.

\section{Clinical Trial Registries}

The following clinical trial registries were searched using terms de- scribing homeless, HIV/AIDS, sexual behaviour: clinicaltrials.gov and WHO International Clinical Trials Registry Platform. We also searched clinical trial registries using the author names of each potentially eligible study to identify additional studies they may have been, or may currently be actively involved in.

\section{Data collection and analysis}

\section{Selection of studies}

See also Figure 1.

The titles and abstracts of all studies identified by electronic searches were screened by two independent authors ( $\mathrm{VN}$ and AM) to shortlist studies for possible inclusion in the review. Full manuscripts of short listed studies were obtained and scrutinized independently by two reviewers (VN and $\mathrm{AM}$ ) to establish eligibility based on design, participants, intervention and outcomes reported. Neither author was blinded to the names of authors, institutions, journal of publication or results. Disagreements were handled initially by discussion between reviewers and if no agreement resulted, a third reviewer (QAK) was consulted. 
Figure I. PRISMA Diagram showing identification, screening, eligibility and inclusion of studies in this review.

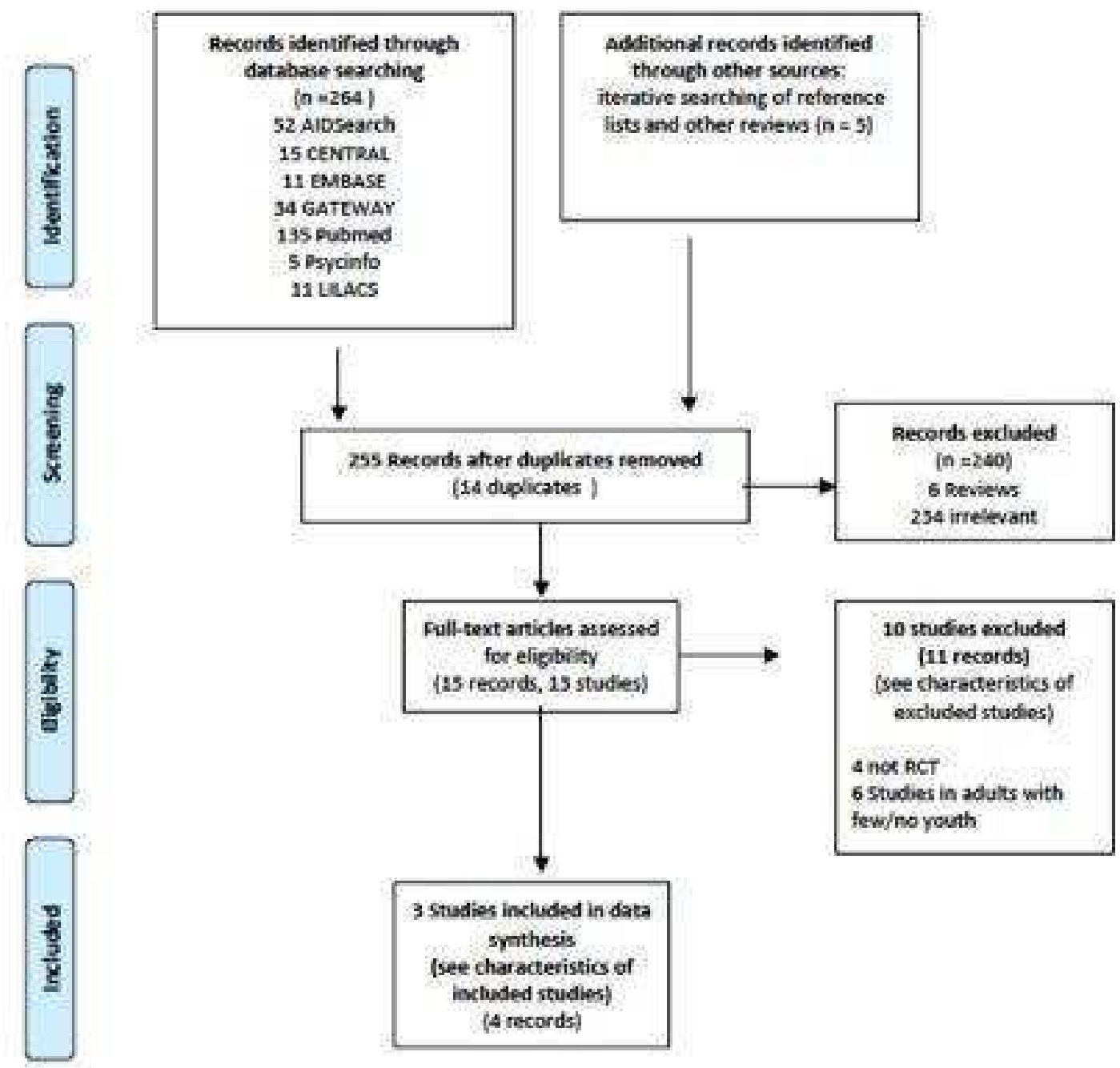

\section{Data extraction and management}

Data from eligible studies were extracted by two independent reviewers (VN and $\mathrm{AM}$ ) onto standardized data collection forms and entered into Review Manager 5.

\section{Assessment of risk of bias in included studies}

The methodological rigor of the studies was independently assessed by two reviewers using the Cochrane Collaboration's tool for assessing risk of bias to assess the risk of selection, performance, attrition, and detection bias. Briefly, the following domains were evaluated and rated as "adequate," "inadequate," or "unclear": sequence generation; allocation concealment; blinding of participants, personnel, or outcome; incomplete outcome data; selective outcome reporting; and other sources of bias.

\section{Measures of treatment effect}

For RCTs, we attempted to calculate the RR for dichotomous outcomes and the $95 \% \mathrm{CI}$. For continuous data, we aimed to calculate a weighted-mean difference. Due to the significant heterogeneity in types of interventions, types of outcomes reported and the lack of reporting standard, we were unable to combine data for meta- 
analysis.

\section{Dealing with missing data}

For missing or ambiguous data, authors of the studies were contacted both at eligibility assessment and data abstraction stages. We received responses from all except one of the authors contacted (7/8).

\section{RE S U L T S}

\section{Description of studies}

See: Characteristics of included studies; Characteristics of excluded studies; Characteristics of ongoing studies.

\section{Results of the search}

As at January 2010, we obtained a total of 255 unique reports by our search strategy (see Figure 1). A total of 240 records were eliminated at screening, leaving 15 eligible reports that were examined in detail for eligibility assessment (full text obtained). Of the 15 reports, 11 reports of 10 independent studies were excluded and the remaining four reports detailed three suitable studies eligible for this review (Rotheram-Borus 2003; Slesnick 2005; Slesnick 2008).

\section{Included studies}

See characteristics of Included studies table.

Three randomised controlled trials meeting the eligibility criteria for this review have been included:

- Street Smart, $\mathrm{n}=311$, youth 11-18 years (Rotheram-Borus 2003 );

- Ecologically Based Family Therapy (EBFT), n=124, youth 12-17 years (Slesnick 2005);

- Community Reinforcement Approach and HIV prevention (CRA), n=180, youth 14-22 years (Slesnick 2008);

All three trials were performed in the United States of America and recruited substance-abusing male and female adolescents through runaway shelters into randomised controlled trials of independent and non-overlapping behavioural interventions. In all three trials, youth participants (or shelters in the case of one cluster-randomised trial, Rotheram-Borus 2003) were randomised to an intervention or a comparison control group that received the standard of care at that trial site at that time.
The three trials differed in theoretical background, delivery method, dosage (number of sessions,) content and outcome assessments. Additionally each differed in target group: one study targeted the individual, one targeted homeless youth in small groups and one study targeted individuals in their family context. All three trials included self-reported measures of sexual risk behaviour as outcomes but did not include any biological (primary outcome) measures of HIV/STI prevalence or incidence (not reported either at baseline or at intervention assessment). While each trial included HIV prevention messaging, the primary outcomes for each trial included other non sexual-risk behaviour related measures of substance use, HIV knowledge, psychological/ individual functioning and family functioning. These additional outcomes are not included in this review.

We also identified three eligible ongoing studies, shown in the table: Characteristics of ongoing studies. The three studies test three different interventions in populations including or exclusively comprised of homeless youth and are being conducted in the United States of America. One trial (STRIVE 2004-9) has been completed but data were not available for inclusion in this review. The other two trials are due to be completed in 2011 (Nyamathi 2008-11) and 2014 (Nyamathi 2009-14). None of the trials measure HIV incidence as an outcome but do measure baseline HIV prevalence (Nyamathi 2009-14) or HIV-risk behaviour (Nyamathi 2008-11, STRIVE 2004-9).

\section{Excluded studies}

See characteristics of Excluded studies table.

We excluded a total of 10 studies which were of potential relevance but due either to ineligible study design (three studies: Arnold 2007; Booth 1999; Gleghorn 1997) or ineligible study participants (seven studies:Jemmot 2005; Kidder 2007, Lightfoot 2007; Linn 2003; Nyamathi 2001; Rotheram-Borus 2009; Susser 1998) were ineligible for inclusion.

\section{Risk of bias in included studies}

See Risk of bias in included studies.

In general, the included studies had significant risk of bias (see Figure 2, Figure 3). 
Figure 2. Risk of bias graphically presented by study

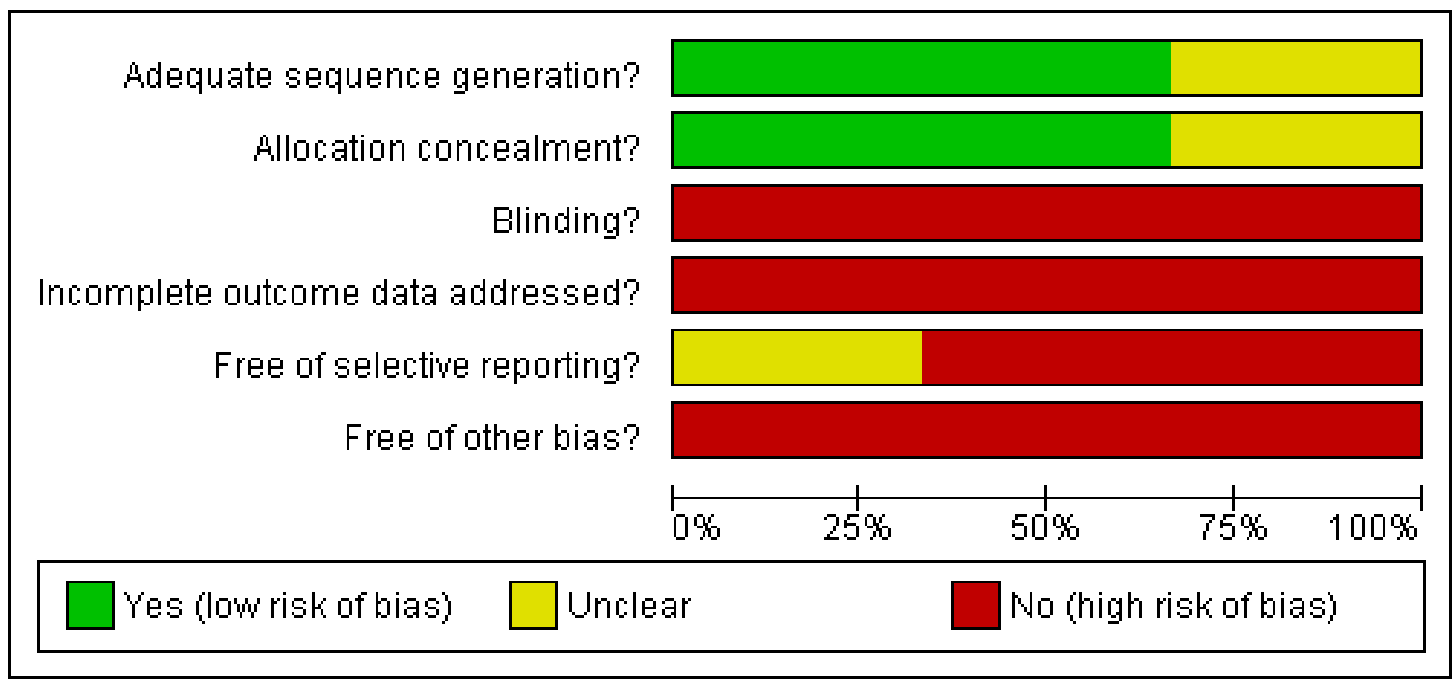

Figure 3. Summary: Risk of bias in included trials

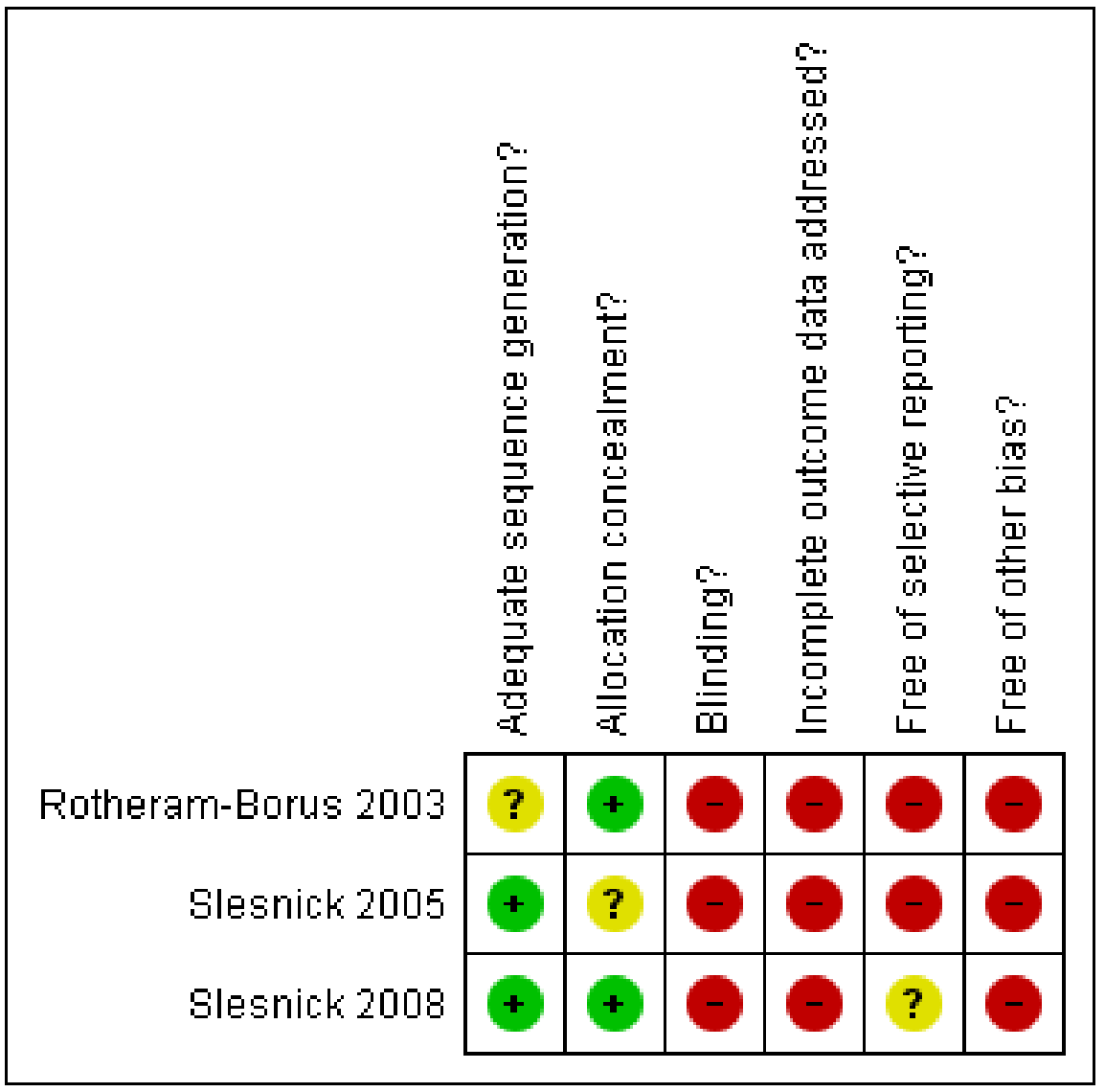

Interventions to modify sexual risk behaviours for preventing HIV in homeless youth (Review)

Copyright (c) 20II The Cochrane Collaboration. Published by John Wiley \& Sons, Ltd. 
All three trials have significant reporting (owing to incomplete outcome reporting) and attrition bias (owing to significant and differential follow-up rates in intervention and control arms). Furthermore the outcome assessment was performed by self report by unblinded participant, there is a significant, but arguably unavoidable, risk of detection bias.

The Street Smart intervention had significant risk of selection and performance bias; while it involved cluster randomizations, no adjustments for clustering/ intra-cluster correlations were reported and randomizations failed to ensure baseline similarity in exposures between intervention and control shelters (propensity scores were however used to try to achieve post-randomization baseline comparability for analysis). Additionally, the Street Smart intervention was not adequately powered for the outcomes of interest.

\section{Effects of interventions}

Due to the heterogeneity and non-traditional types of and reporting of outcomes, we were unable to calculate individual effect measures for outcomes and unable to estimate summary measures of effect . Further, the variability in intervention type precludes meta-analysis. Thus we present descriptive information for each trial.

None of the included trials reported protocol-specified primary outcomes of this review.

In the Street Smart trial, three sexual behaviour outcomes were assessed at 3-,6-12-,18- and 24- months post intervention and reported separately and (graphically only) for males and females (not clearly prespecified) after adjustment for baseline differences by the use of propensity scores (but not for intra-cluster correlation). The outcomes assessed were the total number of sexual partners, the number of unprotected sex acts and abstinence from vaginal or anal sex. We were unable to obtain data to calculate effect sizes or convert reported outcomes to standard outcome measures (RR or weighted mean difference with $95 \%$ confidence intervals) for reported outcomes. Based on reported outcomes in female participants, changes were reported for the number of sexual partners at 24 months (geometric mean number of sex acts in intervention 0.68 times that in control participants, 90\% CI $0.47-0.98, \mathrm{p}<0.10$ ), the frequency of unprotected sexual acts at 3 months (geometric mean frequency of unprotected sexual acts in intervention 0.29 times that in control participants, 90\% CI $0.10-0.83, \mathrm{p}<0.10$ ) and 24 months (geometric mean frequency of unprotected sexual acts in intervention 0.35 times that in control participants, 90\% CI 0.17-0.71, $\mathrm{p}<0.05$ ) and abstinence from unprotected vaginal and anal sex at 18 months (odds of being abstinent in the intervention 2.41 times that in control participants, 90\% CI 1.04-5.58, $\mathrm{p}<0.10$ ). In male participants, no significant effects for any of the sexual behaviour outcomes were reported at any timepoint.
In the EBFT trial, three sexual behaviour outcomes were assessed at 3-,6- and 12-months post intervention. The outcomes assessed were an index of risk based on seven questions (see included studies table), reported condom use and anal sex. No significant effects on sexual behaviour outcomes assessed were reported. Participants in this trial reported relatively low HIV risk behaviours (summarised as approximately 1.4 out of seven for both intervention and control groups on the HIV risk behaviour scale employed).

In the trial of CRA, three sexual behaviour outcomes were assessed at 3- and 6-months post intake. The outcomes assessed were the number of different sexual partners within a 24 hour period and within the last 3 months, and the frequency of condom use. Effects on condom use were reported using a numeric mean of self-reported condom use measured on a Lickert scale (scale: 1 to 5) in sub-analyses by age group (higher in intervention vs. control participants).

\section{DISCUSSION}

\section{Summary of main results}

This review highlights the paucity of well-conducted randomised controlled trials of interventions to modify sexual risk behaviour for preventing HIV in homeless youth. We found three trials fulfilling the eligibility criteria for this review, but were unable to estimate a summary of effect measure for any of the outcomes for this review due to variability in outcomes assessed and intervention type. None of the three included trials measured or reported biological (primary) outcomes. The limitations in the trials preclude assessment of their impact on modifying sexual risk behaviour. Nonetheless, there are several studies in progress (see Characteristics of ongoing studies) that may add evidence to this critical area.

\section{Overall completeness and applicability of evidence}

We included three trials in this review enrolling a total $\mathrm{N}=615$ participants; the paucity of trials is not compensated for by the sample size of the trials. While the participants included were youth, they were limited to urban youth residing in American cities; these may not be applicable to other types of homeless youth, or homeless youth living under different conditions and with different exposures. The interventions tested represent a small sample of the variety of behaviour-change interventions that have been evaluated for HIV (Padian 2010) or other conditions (Fisher 2000). Finally, 
while the trials included here assessed some outcomes relevant to sexual risk behaviours, none assessed or reported biological markers of sexual risk behaviour (pregnancy, STIs or HIV acquisition). Similarly, the trials did not assess or report measures of sexual risk behaviour consistently making it inappropriate to pool data for summary measures of effect.

The studies identified in this review are inadequate to permit evaluation and summary of the effectiveness of interventions for modifying sexual risk behaviours for preventing HIV in homeless youth.

\section{Quality of the evidence}

The body of evidence identified does not permit robust conclusions on the impact of interventions to modify sexual risk behaviour in homeless youth. We assessed these studies to be of low quality (per the GRADE approach) and to have high risk of bias in view of limitations in design and implementation, imprecision of results, and high probability of reporting, attrition, detection, selection and performance bias.

\section{Potential biases in the review process}

This review is robust to quality of design and conduct of studies. We chose to include studies which did not report on the outcomes of interest and were able to obtain these data from authors. Since study quality was not an eligibility criterion, this study is also unlikely to exclude studies based on quality measures.

The major limitation in this review is the inability to estimate summary effect measures or to report on primary outcomes of sexual behaviour change; the included trials reported self-reported behaviours only.

\section{Agreements and disagreements with other studies or reviews}

This review is not the first review of interventions to modify sexual risk behaviour in homeless youth, however its systematic approach differentiates it from three narrative reviews that include the subject (Arnold 2009; Badiaga 2008; Crane 1992) and account for the differences in study inclusion, results and conclusions. In Arnold and Rotheram-Borus' recent review of prevention programs for homeless youth (Arnold 2009), they included six HIV prevention studies (three of which are included in this review, two are excluded due to design (Arnold 2007; Gleghorn 1997 ) and one included though ongoing) and assessed each study by a framework they had previously developed in order to summarise the robust components of interventions for homeless youth. From the evidence assembled in this review, the basis for conclusions on robust elements is weak as there is scant evidence of successful interventions to modify sexual risk behaviour for preventing HIV in homeless youth. In Badiaga and colleagues' review of transmissible diseases in homeless of any age (Badiaga 2008), they review the rationale for interventions to prevent HIV, and highlight one in- tervention targeting homeless youth (Rotheram-Borus 2003) that is included in this systematic review. Crane and Carswell in their early review (Crane 1992), reviewed non-governmental organization-based prevention projects aimed at prevention of sexuallytransmitted infections and HIV in street children. They report on several NGO-based non-randomised controlled interventions that provide service to homeless children. This review did not distinguish between the type of organization that performed the prevention project but aimed to assemble the evidence for interventions to modify sexual risk behaviour in homeless youth that have been rigorously evaluated.

In addition to narrative reviews that have focused on homeless youth, there have been several systematic reviews and meta-analyses of behavioural interventions to reduce HIV-related sexual risk behaviour in defined populations excluding homeless youth (Noar 2008). These include systematic reviews and meta-analysis of behavioural interventions to prevent HIV in adolescents (Johnson 2003; Mullen 2002; ), substance abusing individuals (Copenhaver 2006; Prendergast 2001; Semaan 2002), and individuals with severe mental illness (Johnson-Masotti 2003). Importantly, these reviews highlight the feasibility of bringing about behaviour change. Hence, these reviews enable assessment of what factors characterise effective interventions (see Noar 2008) in populations that share similar characteristics (high rates of substance abuse, mental illness and being adolescents) to homeless youth: such as having a separate approach to participants of different race and gender, including skills-training and having a theory-based component to interventions. These characteristics may also prove to be important moderators of effectiveness in modifying sexual risk behaviour for preventing HIV in homeless youth, but this systematic review is unable to draw conclusions in this regard.

But sexual risk behaviour, particularly when assessed by self-report, is an imperfect correlate of HIV incidence. This underscores the need for HIV prevention efforts to be evaluated in trials with HIV incidence as a directly measured outcome, at least where possible and until we have superior proxy measures for HIV risk. How to prevent HIV remains a major challenge not just in homeless youth but in general; of 37 randomised controlled trials with HIV incidence as the primary or secondary outcome, only 5 trials - three of circumcision (Auvert 2005; Bailey 2007; Gray 2007), one of STI treatment and care (Grosskurth 1995), and one vaccine trial (Rerks-Ngarm 2009) - have shown any positive effect, though none were behavioural interventions (Padian 2010). In addition, only three HIV prevention trials with HIV incidence as an outcome have been performed in adolescents (Ross 2007; Cowan 2008; Jewkes 2008, ), and none have shown any effect thus far. Nonetheless, Padian and colleagues in their review state that "lack of statistical power, poor adherence, and diluted versions of the intervention in comparison groups may have been important issues for the other trials that demonstrated 'flat' results". Similarly, we believe that the lack of effective trials reported in this review need to be seen not just in the light of the unique challenges of working 
with homeless youth, but also the challenge of conducting robust clinical trials.

\section{A U THORS' CONCLUSIONS}

\section{Implications for practice}

The body of evidence from this systematic review limits robust conclusions on implications for practice. The reported success of the interventions in bringing forth some level of change in risk behaviour i.e., a decrease in number of sexual partners and or unprotected sex acts should be viewed with caution. The unintended outcomes of the trials namely to retain sufficient participants for post intervention measures among this very mobile population, in particular for a 24-month period as reported in the Street Smart trial, might be a viewed as a significant outcome that is likely to facilitate other health promoting behavioural change. We believe that the CDC's current policy (DEBI Factsheet 08/09) of supporting the Street Smart approach may need re-examination in view of the body of evidence presented here. More research is required before practice may be changed based on proven interventions in homeless youth.

\section{Implications for research}

This review highlights the high HIV risk in this population and paradoxical paucity of robust randomised controlled trials to evaluate the effectiveness of HIV prevention programmes among homeless youth and underscores an urgent need for more updated risk factor analysis to inform design and implementation of future trials targeting this population (Cohen 2010). Coupled with the growing rates of homelessness amongst orphaned youth in AIDS endemic regions, the UNAIDS mantra of 'know your epidemic' underscores the importance of continued research to monitor homeless youth and their HIV risk and prevalence so that tailored interventions may be robustly evaluated. While the psychosocial and contextual factors that fuel sexual risk behaviours among homeless youth challenge the stringent methodologies of RCTs, novel interventions (e.g., cash transfers or social security interventions (World Bank 2010) and methods for program delivery and trial retention are in need of further development. Strategies to increase retention may include alternative ways of compensating visits or increasing financial compensation. Future trials should comply with rigorous methodology in design, delivery, measurement of risk behaviours and reporting. Using outcome measures that are common across clinical trials may permit fair comparison of various interventions in different populations, and future studies should consider using outcomes based on a common set of standardized outcome measures (for example, indicators for monitoring and evaluating national HIVIAIDS prevention programmes for young people (WHO 2004)). In particular, self-report of risky sexual behavioural change should be supported by biological markers i.e., HIV or STI prevalence and incidence rates as these are more direct measures of effectiveness of interventions to prevent HIV, and may be feasible given the high incidence of HIV amongst homeless youth. The responsibility in ensuring that intervention studies are designed and conducted to the highest standard is balanced by sponsoring agencies who provide resources to conduct these types of studies. The results of three ongoing and potentially eligible studies will be a useful addition to this review.

\section{ACKNOWLEDGEMENTS}

We gratefully acknowledge the support of the staff of the South African Cochrane centre and the HIV/AIDS Review group. In particular we acknowledge the assistance of Joy Olivier and Tara Horvath in assisting with searches, Elizabeth Pienaar, Vicki Badenhorst and Babalwa Zani for their technical support and Nandi Siegfried for her mentorship and guidance during the conduct of this review. We thank Regina El Dib for her translations of the non-English titled abstracts from LILACS for this review.

Funding: VN is supported through a fellowship jointly funded by LIFELab, a South African Department of Science and Technology platform, and the Columbia University-South Africa Fogarty AITRP

Financial support for CAPRISA from the National Institute of Allergy and infectious Disease (NIAID), National Institutes of Health (NIH) (grant\# AI51794) is gratefully acknowledged. 


\section{R E F E R E N C E S}

\section{References to studies included in this review}

Rotheram-Borus 2003 \{published data only (unpublished sought but not used)\}

Rotheram-Borus MJ, Song J, Gwadz M, Lee M, Van Rossem R, Koopman C. Reduction in HIV risk among runaway youth. Prevention science 2003;4(3):173-87.

Slesnick 2005 \{published and unpublished data\} Slesnick N, Prestopnik JL. Ecologically based family therapy outcome with substance abusing runaway adolescents. Journal of Adolescence 2005;28:277-98. [DOI: 10.1016/ j.adolescence.2005.02.008]

Slesnick 2008 \{published and unpublished data\} Slesnick N, Kang M. HIV risk reduction among substanceabusing. Proceedings of the 69th Annual Scientific Meeting of the College on Problems of Durg Dependence. June 16-21 2007, Quebec City, Canada.

* Slesnick N, Kang M.J. The impact of an integrated treatment on HIV risk behavior among homeless youth: a randomized controlled trial. Journal of behavioural medicine Feb 2008;31(1):45-59. [DOI: 10.1007/ s10865-007-9132-5]

\section{References to studies excluded from this review}

Arnold 2007 \{published data only\}

Arnold EM, Walsh AK, Oldham MS, Rapp CA. strengthsbased case management: implementation with high-risk youth. Families in society: the journal of contemporary social services 2007;88(1):86-94.

Booth 1999 \{published data only\}

Booth RE, Zhang Y, Kwiatkwski CF. the challenge of changing drug and sex risk behaviors of runaway and homeless adolescents. Child abuse and neglect 1999;23(12): 1295-306.

Gleghorn 1997 \{published data only\}

Clements KD, Gleghorn AA, Garcia D, Sabin M, Katz M. Can street outreach effectively reach a mobile population of homeless youth?. Proceedings of International Conference on AIDS. 1996; Vol. 11:2:51.

Gleghorn AA, Clements KD, Marx R, Vittinghoff E, LeeeChu P, Katz M. The impact of intensive outreach on HIV prevention activities of homeless, runaway and street youth in San Francisco: the AIDS evaluation of street outreach project (AESOP). AIDS and behaviour 1997;1(4):261-71.

Jemmot 2005 \{published and unpublished data\} Jemmott JB, Jemmott LS, Braverman PK, Fong GT. HIV/ STD reduction interventions for african american and latino adolescent girls at an adolescent medicine clinic: a randomized controlled trial. Archives of pediatrics and adolescent medicine 2005;159(4):440-9.

Kidder 2007 \{published and unpublished data\} Kidder DP, Wolitski RJ, Royal S, Aidala A, CourtenayQuirk C, Holtgrave DR. Access to housing as a structural intervention for homeless and unstably housed people living with HIV: rationale, methods, and implementation of the housing and health study. AIDS and Behavior 2007;11 (Suppl 2):S149-161.

Lightfoot 2007 \{published data only\} Lightfoot MA, Kasirye R, Comulada WS, Rotheram-Borus MJ. Efficacy of a culturally adapted intervention for youth living with HIV in Uganda. Prevention Science 2007;8(4): 271-3.

Linn 2003 \{published data only (unpublished sought but not used)\} Linn LG, Neff JA, Theriot R, Harris JL, Interante J, Graham ME. Reaching impaired populations with HIV prevention programs: a clinical trial for homeless mentally ill african-american men. Cell and Molecular Biology 2003; 49(7):1167-75.

Nyamathi 2001 \{published and unpublished data\} Nyamathi A, Flaskerud JH, Leake B, Dixon EL, Lu A. Evaluating the impact of peer, nurse case-managed, and standard HIV risk-reduction programs on psychosocial and health-promoting behavioral outcomes among homeless women. Research in Nursing and Health 2001;24(5): 410-22.

Rotheram-Borus 2009 \{published and unpublished data\} Rotheram-Borus MJ, Desmond K, Comulada WS, Arnold EM, Johnson M. Reducing risky sexual behavior and substance use among currently and formerly homeless adults living with HIV. American Journal of Public Health 2009;99(6):1100-7.

Susser 1998 \{published and unpublished data\} Susser E, Valenci E, Berkman A, Sohler N, Conover S, Torres J, et al.Human immunodeficiency virus sexual risk reduction in homeless men with mental illness. Archive of Internal Medicine 1998;158(5):266-72.

\section{References to ongoing studies}

Nyamathi 2008-11 \{unpublished data only\} Nyamathi A, colleagues. University of California Los Angeles. An Arts Intervention for Drug-Using Homeless Youth. www.clinicaltrials.gov.

Nyamathi 2009-14 \{unpublished data only\} Nyamathi A, colleagues. University of California, Los Angeles. Hepatitis B Virus (HBV) Prevention for Homeless at Risk for HBV/Hepatitis C Virus (HCV)/HIV. www.clinicaltrials.gov.

STRIVE 2004-9 \{unpublished data only\}

Milburn N, colleagues. University of California, Los Angeles, Center for Community Health. Support To Reunite Involve and Value Each Other (STRIVE). www.clinicaltrials.gov.

\section{Additional references}


Anarfi 1997

Anarfi JK. Vulnerability to sexually transmitted disease: street children in Accra. Health Transition Review 1997;7 Suppl:281-306.

\section{Arnold 2009}

Arnold EM, Rotheram-Borus MJ. Comparisons of prevention programs for homeless youth. Prevention Science 2009;10:76-86.

Auvert 2005

Auvert B, Taljaard D, Lagarde E, Sobngwi-Tambekou J, Sitta R, Puren A. Randomized, controlled intervention trial of male circumcision for reduction of HIV infection risk: the ANRS 1265 trial. PLoS Medicine 2 Nov 2005;2(11: e298):EPub 2005 Oct 25.

\section{Badiaga 2008}

Badiaga S, Raoult D, Brouqui P. Preventing and controlling emerging and reemerging transmissible diseases in the homeless. Emerging Infectious Diseases 9 September 2008;14 (9):1353-9.

Bailey 2007

Bailey RC, Moses S, Parker CB, Agot K, Maclean I, Krieger JN, Williams CF, Campbell RT, Ndinya-Achola JO. Male circumcision for HIV prevention in young men in Kisumu, Kenya: a randomised controlled trial. Lancet 24 Feb 2007; 369(9562):643-56.

\section{Barker 1993}

Barker G. Research on AIDS: knowledge, attitudes and practices among street youth. Children Worldwide 1993;20 (2-3):41-2.

Baybuga 2004

Baybuga MS, Celik SS. The level of knowledge and views of the street children/youth about AIDS in Turkey. International Journal of Nursing Studies 2004;41 (6):591-7.

\section{Bernier 1995}

Bernier M, Ascensio P. [Street children and AIDS in Haiti]. Sante. 1995;5(2):125-30.

Black 1997a

Black B, Farrington AP. Preventing HIV / AIDS by promoting life for Indonesian street children. Aidscaptions 1997;4(1):14-7.

\section{Black 1997b}

Black B, Farrington AP. Promoting life for Indonesia’s street children. AIDSlink 1997;45:10-1.

\section{Boivin 2005}

Boivin JF, Roy E, Haley N, Galbaud du Fort G. The health of street youth: a Canadian perspective. Canadian Journal of Public Health 2005;96(6):432-7.

\section{Cauce 2000}

Cauce A, Paradise M, Ginzler J, Embry L, Morgan C, Lohr Y. The characteristics of mental health of homeless adolescents: age and gender differences. Journal of Emotional and Behavioural Disorders 2000;8(4):230-9.

\section{Chinazo 2007}

Chinazo O, Cunningham MD, Sanches JP, Heller DI, Sohler NL. Assessment of a medical outreach program to improve access to HIV care among marginalized individuals. American Journal of Public Health 2007;97(10):1758-61.

\section{Clements 1997}

Clements K, Gleghorn A, Garcia D, Katz M, Marx R. A risk profile of street youth in northern California: implications for gender-specific human immunodeficiency virus prevention. Journal of Adolescent Health 1997;20(5): $343-53$.

\section{Cohen 2010}

Cohen J. HIV moves in on homeless youth. Science 9 Jul 2010;329(5988):170-1.

\section{Copenhaver 2006}

Copenhaver MM, Johnson BT, Lee I, Harman JJ, Carey MP. Behavioral HIV risk reduction among people who inject drugs: meta-analytic evidence of efficacy. Journal of Substance Abuse Treatment 2006;31:163-71.

\section{Cowan 2008}

Cowan FM, Pascoe SL, Langhau LF, Dirawo J, Chidiya S, Jaffar S, et al.The Regai Dzive Shiri project: a cluster randomised controlled trial to determine the effectiveness of a multicomponent community-based HIV prevention intervention for rural youth in Zimbabwe - study design and baseline results. Tropical Medicine \& International Health 2008;13(10):1235-44.

\section{Crane 1992}

Crane SF, Carswell JW. A review and assessment of nongovernmental organization-based STI/AIDS education and prevention projects for marginalized groups. Health Education Research 1992;7(2):175-94.

\section{de Carvalho 2006}

de Carvalho FT, Neiva-Silva L, Ramos MC, Evans J, Koller $\mathrm{SH}$, Piccinini $\mathrm{CA}$, et al.Sexual and drug use risk behaviors among children and youth in street circumstances in Porto Alegre, Brazil. AIDS and Behavior 2006;10(4 Suppl): S57-66.

\section{DEBI Factsheet 08/09}

Diffusion of Effective Interventions Project. http:// www.effectiveinterventions.org/en/home.aspx (accessed [October 2010])

\section{DeMatteo 1999}

DeMatteo D, Major C, Block B, Coates R, Fearon M, Goldberg E, et al.Toronto street youth and HIV/AIDS: prevalence, demographics, and risks. Journal of Adolescent Health 1999;25(5):358-66.

\section{DiClemente 1995}

DiClemente RJ, Wingood GM. A randomized controlled trial of an HIV sexual risk-reduction intervention for young African-American women. Journal of the American Medical Association 1995;274(16):1271-6.

\section{Doyle AM 2010}

Doyle AM, Napierala MS, Ross DA. HIV prevention in young people in sub-Saharan Africa: a systematic review and update of the evidence (WEAC0201). XVIII International AIDS Conference (AIDS 2010). Vienna, Austria, 2010. 


\section{Fisher 2000}

Fisher JD, Fisher WA. Theoretical approached to individual-level change in HIV risk behavior. In: Peterson, DiClemente editor(s). Handbook of HIV Prevention. New York: Kluwer Academic/Plenum, 2000:3-55.

\section{Gatu 2000}

Gatu R. Solomon Islands: reaching street children in Honiara. Pacific AIDS Alert Bulletin 2000;19:11.

\section{Gleghorn 1998}

Gleghorn A, Marx R, Vittinghoff E, Katz M. Association between drug use patterns and HIV risk among homeless, runaway, and street youth in Northern California. Drug and Alcohol Dependence 1998;51:219-27.

\section{Gray 2007}

Gray RH, Kigozi G, Serwadda D, Makumbi F, Watya S, Nalugoda F, et al.Male circumcision for HIV prevention in men in Rakai, Uganda: a randomised trial. Lancet $24 \mathrm{Feb}$ 2007;369(9562):657-66.

\section{Greene 1997}

Greene J, Ringwalt C, Iachan R. Shelters for runaway and homeless youths: capacity and occupancy. Child Welfare 1997;76:549-561.

\section{Greene 1999}

Greene JM, Ennett ST, Ringwalt CL. Prevalence and correlates of survival sex among runaway and homeless youth. American Journal of Public Health 1999;89(9): 1406-9.

\section{Grosskurth 1995}

Grosskurth H, Todd J, Mwijarubi E, Mayaund P, ka-Gina G, Mabey D, et al.Impact of improved treatment of sexually transmitted diseases on HIV infection in rural Tanzania: randomised controlled trial. Lancet 26 August 1995;346 (8974):530-6.

\section{Halcon 2004}

Halcon L, Lifson A. Prevalence and predictors of sexual risks among homeless youth. Journal of Youth and Adolescence 2004;33(1):71-80.

\section{Haley 2004}

Haley N, Roy E, Leclerc P, Boudreau JF, Boivin JF. HIV risk profile of male street youth involved in survival sex. Sexually Transmitted Infections 2004;80(6):526-30.

\section{Hammer 2002}

Hammer H, Finkelhor D, Sedlak A. Runaway/ thrownaway children: national estimates and characteristics. http:// www.ncjrs.org/pdffiles 1/ojjdp/196469.pdf 2002 (accessed [8 Mar 2008]).

\section{Jewkes 2008}

Jewkes R, Nduna M, Levin J, Jama N, Dunkle K, Puren A, et al.Impact of stepping stones on incidence of HIV and HSV-2 and sexual behaviour in rural South Africa: cluster randomised controlled trial. British Medical Journal 2008; 337:a506.

\section{Johnson 2003}

Johnson BT, Carey MP, Marsh KL, Levin KD, Scott-Shelfon LAJ. Interventions to reduce sexual risk for the Human
Immunodeficiency Virus in adolescents, 1985-2000: a research synthesis. Archives of Pediatric and Adolescent Medicine 2003;157:381-8.

\section{Johnson-Masotti 2003}

Johnson-Masotti AP, Weinhardt LS, Pinkerton SD, Otto-Salaj LL. Efficacy and cost-effectiveness of the first generation of HIV prevention interventions for people with severe mental illness. The Journal of Mental Health Policy and Economics 2003;6:23-35.

\section{Kegeles 1996}

Kegeles SM, Hays RB, Coates TJ. The Mpowerment Project: a community-level HIV prevention intervention for young gay men. American Journal of Public Health 1996; 86(8):1129-36.

Kelly 2003

Kelly PJ, Grajcer B, Rigato FD. Children Living on the Street. Online Brazilian Journal of Nursing 2003; Vol. 2, issue 2:www.uff.br/nepae/objn202kellyetal.htm (accessed [5 March 2008]).

\section{Kidd 2004}

Kidd S, Scrimenti K. Evaluating child and youth homelessness. Evaluation Review 2004;28(4):325-41.

\section{Kipke 1995}

Kipke MD, O'Connor S, Palmer R, MacKenzie RG. Street youth in Los Angeles: profile of a group at high risk for Human Immunodeficiency Virus infection. Archives of Pediatric and Adolescent Medicine 1995;149(5):513-9.

\section{Kissin 2007}

Kissin DM, Zapata L, Yorick R, Vinogradova EN, Volkova GV, Cherkassova E, et al.HIV seroprevalence in street youth, St Petersburg, Russia. AIDS 2007;21:2333-40.

\section{Klein 2000}

Klein J, Woods A, Wilson K, Prospero M, Greene J, Ringwalt C. Homeless and runaway youths' access to health care. Journal of Adolescent Health 2000;27:331-9.

\section{Lambert 2005}

Lambert M, Torrico F, Billot C, Mazina D, Marleen B, Van der Stuyft P. Street youths are the only high-risk group for HIV in a low-prevalence South American country. Sexually Transmitted Diseases 2005;32(4):240-2.

\section{Luna 1991}

Luna GC. Street youth: adaptation and survival in the AIDS decade. Journal of Adolescent Health 1991;12(7): $511-4$.

\section{MacDonald 1994}

MacDonald NE, Fisher WA, Wells GA, Doherty JA, Bowie WR. Canadian street youth: correlates of sexual risk-taking activity. Pediatric Infectious Disease Journal 1994;13(8): 690-7.

\section{MacLean 1999}

MacLean M, Embry L, Cauce A. Homeless adolescents' paths to separation from family: comparison of family characteristics, psychological adjustment, and victimization. Journal of Community Psychology 1999;27(2):179-87. 
Malamud 1995

Malamud S. At risk and abandoned: street children, AIDS and human rights. AIDSlink 1995;31:6-7.

Mantell 1997

Mantell JE, DiVittis AT, Aurbach MI. Evaluating HIV prevention interventions. New York: Plenum Press, 1997.

Milburn 2007

Milburn NG, Stein JA, Rice E, Rotheram-Borus MJ, Mallett $S$, Rosenthal D, et al.AIDS risk behaviors among American and Australian homeless youth. Journal of Social Issues 2007;63:543-65.

Moore 2006

Moore J. Unaccompanied and homeless youth: review of the literature (1995-2005). http:// www.cde.state.co.us/cdeprevention/download/pdf/ Homeless\%20Youth\%20Review\%20of\%20Literature.pdf 2006 (accessed [5 Mar 2008]).

Mullen 2002

Mullen PD, Ramirez G, Strouse D, Hedges LV, Sogolow E. Meta-analysis of the effects of behavioral HIV prevention interventions on the sexual risk behavior of sexual experienced adolescents in controlled studies in the United States. Journal of Acquired Immune Deficiency Syndromes 2002;30:S94-105.

Noar 2008

Noar SM. Behavioral interventions to reduce HIV-related sexual risk behavior: review and synthesis of meta-analytic evidence. AIDS and Behavior 2008;12:335-53.

\section{Ommundsen 1993}

Ommundsen C. [Brazil: street children in the risk zone for HIV and AIDS]. Vardfacket 1993;17(13):24-5.

\section{Padian 2010}

Padian NS, McCoy SI, Balkus JE, Wasserheit JN. Weighting the gold in the gold standard: challenges in HIV prevention research. AIDS 2010;24:621-35.

Panter-Brick 2002

Panter-Brick C. Street children, human rights, and public health: a critique and future directions. Annual Review of Anthropology 2002;31(1):147-71.

Pennbridge 1992

Pennbridge JN, Freese TE, MacKenzie RG. Highrisk behaviors among male street youth in Hollywood, California. AIDS Education and Prevention 1992;Fall Suppl:24-33.

\section{Podschun 1993}

Podschun GD. Teen Peer Outreach-Street Work Project: HIV prevention education for runaway and homeless youth. Public Health Reports 1993;108(2):150-5.

\section{Poulin 2001}

Poulin C, Alary M, Bernier F, Carbonneau D, Boily MC, Joly JR. Prevalence of Chlamydia trachomatis and Neisseria gonorrhoeae among at-risk women, young sex workers, and street youth attending community organizations in Quebec City, Canada. Sexually Transmitted Diseases 2001;28(8): $437-43$.

\section{Prendergast 2001}

Prendergast ML, Urada D, Podus S. Meta-analysis of HIV risk-reduction interventions within drug abuse treatment programs. Journal of Consulting and Clinical Psychology 2001;69:389-405.

\section{Raffaelli 2003}

Raffaelli M, Campos R, Merritt AP, Siqueira E, Antunes $\mathrm{CM}$, Parker R, et al.Sexual practices and attitudes of street youth in Belo Horizonte, Brazil. Social Science \& Medicine 1993;37(5):661-70.

\section{Raleigh-DuRoff 2004}

Raleigh-DuRoff C. Factors that influence adolescents to leave or stay living on the street. Child and Adolescent Social Work Journal 2004;21(6):561-72.

\section{Ramphele 1997}

Ramphele MA. Adolescents and violence: "adults are cruel: "they just beat, beat, beati ${ }^{\circ}$. Social Science \& Medicine 1997; 45(8):1189-97.

\section{Rerks-Ngarm 2009}

Rerks-Ngarm S, Pitisuttithum P, Nitayaphan S,

Kaewkungwal J, Chiu J, Paris R, et al.Vaccination with ALVAC and AIDSVAX to prevent HIV-1 infection in Thailand. New England Journal of Medicine 3 Dec 2009; 361 (23):2209-20.

Rew 2001

Rew L, Taylor-Seehafer M, Thomas N, Yockey R. Correlates of resilience in homeless adolescents. Journal of Nursing Scholarship 2001;33(1):33-40.

\section{Ribeiro 200}

Ribeiro M, Trench Ciampone M. Homeless children: the lives of a group of Brazilian street children. Journal of Advanced Nursing 2001;35:42-9.

\section{Richter 1995}

Richter LM, Swart-kruger J. AIDS-risk among street children and youth: implications for intervention. South African Journal of Psychology 1995;25(1):31-8.

\section{Ringwalt 1998}

Ringwalt C, Greene J, Robertson M. Familial backgrounds and risk behaviours of youth with throwaway experiences. Journal of Adolescence 1998;21:241-52.

\section{Robbins 2010}

Robbins CL, Zapata L, Kissin DM, Shevchenko N, Yorick $\mathrm{R}$, Skipalska H, et al.Multicity HIV seroprevalence in street youth, Ukraine. International Journal of STD \& AIDS 2010;21:489-96.

Robinson 2001

Robinson T, Thompson T, Bain B. Sexual risk-taking behavior and HIV knowledge of Kingston's street boys. Journal of AIDS Prevention \& Education of Adolescent Children 2001;4:127-47.

\section{Rohde 2001}

Rohde P, Noell J, Ochs L, Seeley J. Depression, suicidal ideation and STD-related risk in homeless older adolescents. Journal of Adolescence 2001;24:447-60. 


\section{Rosenthal 2007}

Rosenthal D, Mallett S, Gurrin L, Milburn N, RotheramBorus MJ. Changes over time among homeless young people in drug dependency, mental illness and their comorbidity. Psychology, Health \& Medicine 2007;12(1): 70-80.

Ross 2006

Ross DA, Dick B, Ferguson J. Preventing HIV/AIDS in young people: a systematic review of the evidence from developing countries. UNAIDS Technical Report Series 2006, issue 938 .

\section{Ross 2007}

Ross DA, Changalucha J, Obasi AI, Todd J, Plummer ML, Cleophas-Mazige B, et al.Biological and behavioural impact of an adolescent sexual health intervention in Tanzania: a community randomized trial. AIDS 12 Sep 2007;21(14): $1943-55$.

Rotheram-Borus 1993

Rotheram-Borus MJ, Song J, Gwadz M, Lee M, Van Rossem R, Koopman C. Reductions in HIV risk among runaway youth. Prevention Science 1993;4(3):173-87.

\section{Rotheram-Borus 1996}

Rotheram-Borus MJ, Mahler KA, Koopman C, Langabeer K. Sexual abuse history and associated multiple risk behavior in adolescent runaways. American Journal of Orthopsychiatry 1996;66(3):390-400.

\section{Rotheram-Borus 1997}

Rotheram-Borus M, Van Rossem R, Gwadz M, Koopman C, Lee M. Reductions in HIV risk among runaway youths. http://www.cdc.gov/hiv/resources/reports/ hiv' compendium/section1-23.htm.

\section{Rotheram-Borus 1999}

Rotheram-Borus MJ, Koopman C, Haignere C, Davies M. Reducing HIV sexual risk behaviours among runaway adolescents. Journal of the American Medical Association 1999;266(9):1237-41.

\section{Roy 2000}

Roy E, Haley N, Leclerc P, Lemire N, Boivin JF, Frappier JY, et al.Prevalence of HIV infection and risk behaviours among Montreal street youth. Int J STD AIDS. International Journal of STD \& AIDS 2000;11(4):241-7.

Roy 2003

Roy E, Haley N, Leclerc P, Cedras L, Weber AE, Claessens $\mathrm{C}$, et al.HIV incidence among street youth in Montreal, Canada. AIDS 2003;17(7):1071-5.

\section{Roy 2004}

Roy E, Haley N, Leclerc P, Sochanski B, Boudreau JF, Boivin JF. Mortality in a cohort of street youth in Montreal. Journal of the American Medical Association 2004;292(5): 569-74.

Ruiz 1994

Ruiz J. Street youth in Colombia: lifestyle, attitudes and knowledge. AIDS Health Promotion Exchange 1994;1:12-4.

\section{Semaan 2002}

Semaan S, Jarlais DCD, Sogolow E, Johnson WD, Hedges GR, Flores SA, et al.A meta-analysis of the effect of HIV prevention interventions on the sex behaviors of drug users in the United States. Journal of Acquired Immune Deficiency Syndromes 2002;30:573-593.

\section{Snell 2002}

Snell CL. Help-seeking and risk-taking behavior among Black street youth: implications for HIV/AIDS prevention and social policy. Journal of Health \& Social Policy 2002;16 (1-2):21-32.

\section{Swart-Kruger 1997}

Swart-Kruger J, Richter LM. AIDS-related knowledge, attitudes and behaviour among South African street youth: reflections on power, sexuality and the autonomous self. Social Science \& Medicine 1997;45(6):957-66.

\section{Taylor 2004}

Taylor D, Lyndon J, Bougie E, Johannsen K. ”Street kids“: toward an understanding of their motivational context. Canadian Journal of Behavioural Science 2004;36(1):1-16.

\section{Tenner 1998}

Tenner AD, Trevithick LA, Wagner V, Burch R. Seattle YouthCare's prevention, intervention, and education program: a model of care for HIV-positive, homeless, and at-risk youth.. The Journal of Adolescent Health 1998;23(2 Suppl):96-106.

\section{UNAIDS 2004}

UNAIDS/WHO. AIDS epidemic update. 2004.

UNAIDS 2007

UNAIDS. AIDS epidemic update. December 2007.

\section{UNAIDS 2009}

UNAIDS. AIDS epidemic update. November 2009; Vol. UNAIDS/09.36E/JC1700E.

\section{Underhill 2008}

Underhill K, Montgomery P, Operario D. Abstinence-plus programs for HIV infection prevention in high-income countries. Cochrane Database of Systematic Reviews 2008, Issue 1.

United Nations 2007

United Nations: Department of Economic and Social Affairs. World Youth Report 2007: Young people's transition to adulthood: progress and challenges. 2007. [: ISBN 978-92-1-130257-8]

\section{Unknown 1995}

No authors listed. Street children turn to sex-work to survive. AIDS Analysis Africa 1995 Aug;5(4):6-7.

\section{US Code Title 42}

United States Code. Title 42, Chapter 119, Subchapter I, subsection 11302 .

van den Hoek 1997

van den Hoek A. STD control in drug users and street youth. Genitourinary Medicine 1997;73(4):240-4. 


\section{Van Wormer 2003}

Van Wormer R. Homeless youth seeking assistance: a research-based study from Duluth, Minnesota. Child and Youth Forum 2003;32(2):89-103.

\section{Walters 1999}

Walters AS. HIV prevention in street youth. Journal of Adolescent Health 1999;25(3):187-98.

\section{WHO 2004}

National AIDS programs: A guide to indicators for monitoring and evaluating national HIV/AIDS prevention programmes for young people.. http://www.unaids.org/en/ in + focus/monitoringevaluation/ $\mathrm{m}$ e+library.asp (accessed [6 Feb 2008]).

\section{World Bank 2010}

The World Bank. Cash payments can reduce HIV/Sexually Transmitted Infections in Africa? New Bank studies. Press release no: 2011/027/HDN 18 July 2010.

* Indicates the major publication for the study 
CHARACTERISTICS OF STUDIES

Characteristics of included studies [ordered by study ID]

Rotheram-Borus 2003

\begin{tabular}{|c|c|}
\hline Methods & Cluster randomised controlled trial (start and end dates not reported) \\
\hline Participants & $\begin{array}{l}\text { Four shelters in two clusters constituting a total of } 311 \text { runaway youth (11-18 years } \\
\text { age, } 49 \% \text { female) admitted to one of three runaway shelters in New York City, USA } \\
\text { or one runaway shelter in New Jersey, USA. The ethnicity of participants were: African } \\
\text { American }(59 \%) \text {, Hispanic }(26 \%) \text { and white/other }(15 \%) \text {. The HIV status of participants } \\
\text { was not assessed/reported }\end{array}$ \\
\hline Interventions & 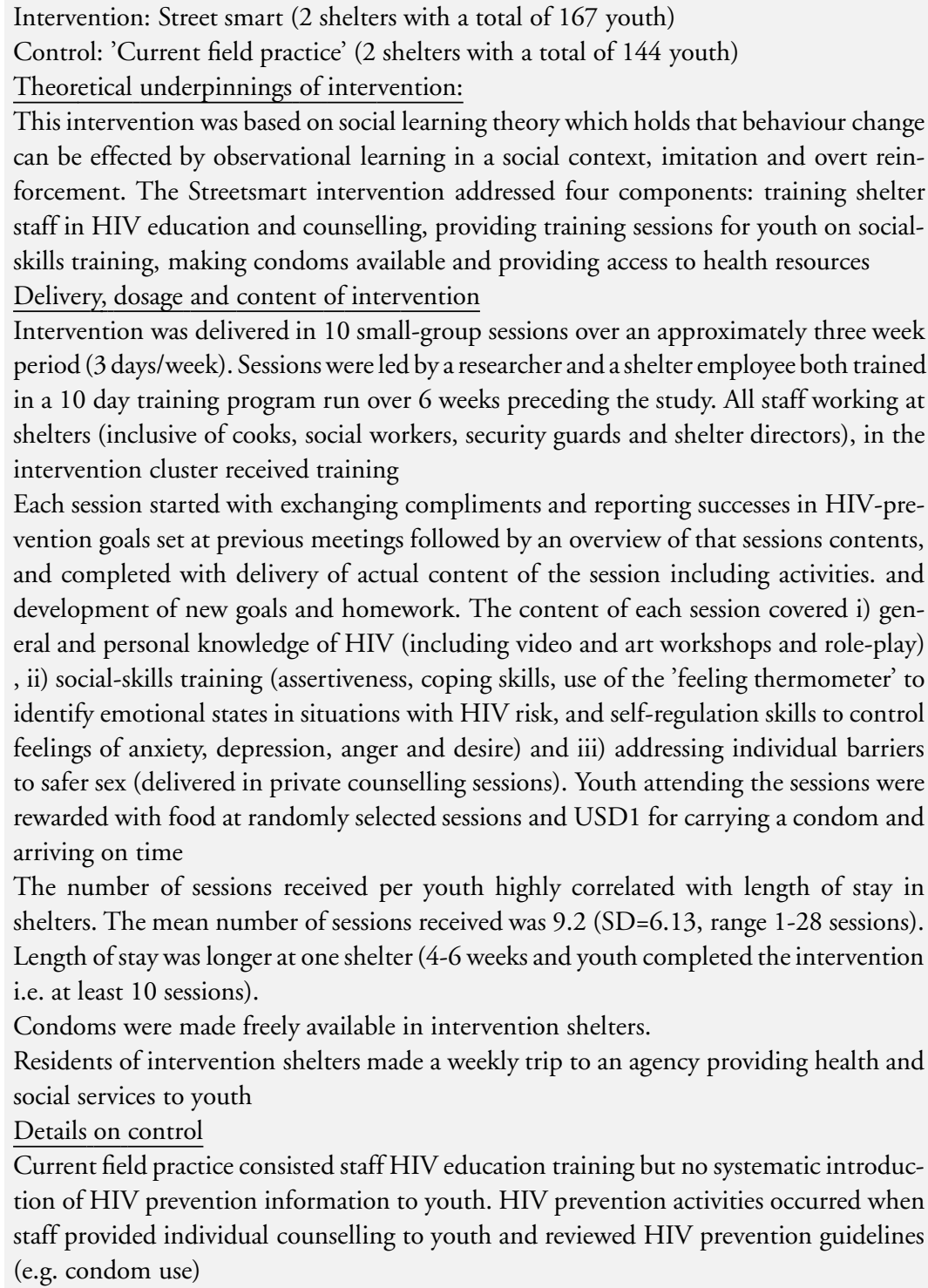 \\
\hline
\end{tabular}




\begin{tabular}{l|l} 
Outcomes & $\begin{array}{l}\text { Sexual risk acts were evaluated through a } 45-\text { min structured interview at baseline, 3-,6- } \\
, 12-, 18-\text { and } 24-\text { months post intervention with each individual study participant by } \\
\text { a staff interviewer not aware of the intervention status of the individual . During the } \\
\text { interview participants reported the number of partners, specific sexual acts and whether } \\
\text { condoms were used during each act. Three indices were calculated and reported: } \\
\text { 1. total number of sexual partners, } \\
\text { 2. the number of unprotected sex acts and, } \\
\text { 3. abstinence from vaginal or anal sex. } \\
\text { Outcomes were reported graphically for males and females separately and as ratios of } \\
\text { the means for the number of sexual acts, frequency of unprotected acts and as odds ratios } \\
\text { for abstinence from unprotected sexual acts }\end{array}$ \\
\hline Notes & $\begin{array}{l}\text { Investigators explain that it would not have been feasible to mount a properly powered } \\
\text { trial consisting } 22 \text { shelters }\end{array}$
\end{tabular}

\section{Risk of bias}

\begin{tabular}{lll}
\hline Item & Authors' judgement & Description \\
\hline Adequate sequence generation? & Unclear & Randomization procedure not reported. \\
\hline Allocation concealment? & Yes & $\begin{array}{l}\text { Cluster randomised-prior to triage of par- } \\
\text { ticipants to shelter }\end{array}$ \\
\hline $\begin{array}{l}\text { Blinding? } \\
\text { All outcomes }\end{array}$ & No & $\begin{array}{l}\text { Participants and personnel were not uni- } \\
\text { formly blinded to study intervention and } \\
\text { while study staff interviewers (assessors) } \\
\text { were blinded to intervention, participants } \\
\text { self-reporting were not }\end{array}$ \\
\hline
\end{tabular}

Incomplete outcome data addressed? No

All outcomes

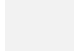

Differential, variable and large loss to follow up at each follow up period for both arms reported without reasons for loss. Losses were 76/167 and 58/144, 77/167 and 53/144, 98/167 and 58/144, 103/167 and $66 / 144,57 / 167$ and $37 / 144$ for intervention and control arms at 3-,6-,12-,18and 24 months
Free of selective reporting?

No

No

In analysis, individuals with the lowest or highest risk behaviour were excluded as were youth who could not be matched to others based on propensity scores

Free of other bias?
Intervention and control groups differed significantly at baseline (randomizations by shelter failed to eliminate bias adequately) . Propensity scores were used to adjust for 
Rotheram-Borus 2003 (Continued)

\begin{tabular}{|l|l} 
differences at baseline prior to data analysis \\
While cluster randomizations was con- \\
ducted, no control for cluster effect was re- \\
ported and outcomes were reported as for \\
randomizations at the individual level \\
Per protocol assessment reported (youth \\
who rotated through other shelters were \\
excluded from analysis). Intention to treat \\
would have been preferred
\end{tabular}

Slesnick 2005

Methods

Participants

Interventions
Randomised controlled trial (start and end dates not reported)

124 substance-abusing adolescents (12-17 years age, $59 \%$ female, $52 \%$ enrolled in school) referred from one of two runaway shelters in New Mexico,USA after a runaway episode with a history of at least 10 days of substance use in preceding 90 days, fulfilling criteria for at least one DSM-IV psychoactive substance use disorder and living within 60 miles of the two runaway shelters through which they were recruited. In addition, a parent/surrogate willing to participate was an inclusion criteria. Potential participants whose primary drug of abuse was alcohol were excluded, as were participants with unremitting psychosis or adolescents with no option to return to their home. The ethnicity of the participants were: Anglo ( $n=46)$, African American $(n=9)$, Hispanic ( $n=51)$, native American $(n=5)$ and other $(n=13)$. HIV status of participants were not reported. Sexual orientation of participants were not reported. The HIV status of participants was not assessed/reported

Intervention:Ecologically based family therapy (EBFT) $(n=65)$

Control: Treatment/service as usual $(\mathrm{n}=59)$

Adolescents in both the intervention and control arm were free to obtain outside treatment

Theoretical underpinnings of intervention:

This intervention was based on the homebuilders family preservation model based on crisis intervention theory (families are most open to change when in a crisis). A multisystemic treatment approach as per the multisystemic treatment model (behavioural problems in runaway youth are multiply determined and best addressed by multiple layers of interventions) was adopted here i.e.. approaching adolescents and parents individually first, then together, then approaching the extended family and involving other key role players in the life of the adolescents. Techniques including cognitive-behavioural therapy and behavioural family therapy were used

$\underline{\text { Delivery, dosage and content of intervention }}$ 
Slesnick 2005 (Continued)

\begin{tabular}{|c|c|c|}
\hline & \multicolumn{2}{|c|}{$\begin{array}{l}\text { Intervention was delivered in four phases over } 15 \text { sessions by therapists trained in be- } \\
\text { havioural, cognitive and environmental interventions. Four sessions focusing specifically } \\
\text { on HIV prevention were incorporated in the first phase of intervention when the indi- } \\
\text { vidual adolescent was engaged. The number of sessions in each phase of intervention } \\
\text { and the detailed content were not reported but could be grouped into four phases: } \\
\text { - Phase 1: Individual sessions (number not reported) in which adolescents and } \\
\text { parents were separately seen with the aim to engage and motivate each for discussion } \\
\text { and identifying issues that may have initiated the runaway episode. Attempts were } \\
\text { made to develop parents readiness to accept a new relationship with the adolescent and } \\
\text { competencies in parenting. } \\
\text { - Phase } 2 \text { : 'Family session' targeting specific dysfunctional interactions which } \\
\text { correspond to the development and continuation of problem behaviours in which the } \\
\text { adolescent and their parent figure are seen together. } \\
\text { - Phase } 3 \text { : Key role-players are involved (siblings, extended family members etc.) } \\
\text { - Phase } 4 \text { : The final two sessions dealt with issues of termination. } \\
\text { Participants were remunerates USD25 at completion of pretreatment and 3-month out- } \\
\text { come visits, and UDSD50 at completion of } 6 \text { - and } 12 \text {-month outcome visits } \\
\text { Details on control } \\
\text { Treatment as usual consisted housing the adolescent in the runaway shelter. Adolescents } \\
\text { were housed in the shelter for a short time average of nine days SD } 17.5 \text { days and } \\
\text { pretreatment assessment and } 14 \text { days at post-treatment assessment. Shelter provided for } \\
\text { youth needs i.e. food, shelter, clothing, crises intervention and assistance with placements }\end{array}$} \\
\hline Outcomes & \multicolumn{2}{|c|}{$\begin{array}{l}\text { HIV risk behaviour's as composite score out of } 7 \text { assessed by self-report behaviours (in } \\
\text { a } 3 \text { hour diagnostic battery of self-report forms) at baseline, 3-, 6- and 12-months-post- } \\
\text { intervention. The HIV risk behaviour score was calculated based on self report answers } \\
\text { to seven questions on risk behaviour in the preceding three months: } \\
\text { 1. Injected drug use; } \\
\text { 2. had sex with two or more sex partner; } \\
\text { 3. had high-risk sex partners; } \\
\text { 4. 'had STD/AIDS risk'; } \\
\text { 5. had anal sex; } \\
\text { 6. reported usage of a condom; } \\
\text { 7. engaged in survival sex. } \\
\text { Outcomes obtainable from authors and eligible for inclusion in this review were: the } \\
\text { composite HIV risk behaviour score and the individual outcomes of condom use and } \\
\text { anal sex }\end{array}$} \\
\hline Notes & \multicolumn{2}{|c|}{$\begin{array}{l}\text { Outcomes were not reported by arm in published reports. We obtained data from the } \\
\text { authors for intent-to treat analysis }\end{array}$} \\
\hline \multicolumn{3}{|l|}{ Risk of bias } \\
\hline Item & Authors' judgement & Description \\
\hline Adequate sequence generation? & Yes & Urn Randomization used. \\
\hline
\end{tabular}


Slesnick 2005 (Continued)

\begin{tabular}{|c|c|c|}
\hline Allocation concealment? & Unclear & $\begin{array}{l}\text { Insufficient information: following com- } \\
\text { pletion of the assessment battery all youth } \\
\text { were randomised to intervention or control }\end{array}$ \\
\hline $\begin{array}{l}\text { Blinding? } \\
\text { All outcomes }\end{array}$ & No & $\begin{array}{l}\text { Unblinded study (participants and per- } \\
\text { sonnel not blinded). Outcome assessors } \\
\text { (participants self-reporting sexual risk be- } \\
\text { haviour) not blinded }\end{array}$ \\
\hline $\begin{array}{l}\text { Incomplete outcome data addressed? } \\
\text { All outcomes }\end{array}$ & No & $\begin{array}{l}\text { Differential and large loss to follow up (12/ } \\
65 \text { in intervention vs } 15 / 59 \text { in control) }\end{array}$ \\
\hline Free of selective reporting? & No & $\begin{array}{l}\text { Risk behavior outcomes reported as com- } \\
\text { posite scores for all individuals by gender/ } \\
\text { ethnicity/period of assessment and not by } \\
\text { treatment arm in published report. }\end{array}$ \\
\hline Free of other bias? & No & $\begin{array}{l}\text { A large proportion of participants did not } \\
\text { complete the intervention }\end{array}$ \\
\hline
\end{tabular}

\section{Slesnick 2008}

\begin{tabular}{ll}
\hline Methods & Randomised controlled trial (November 2001-August 2005) \\
\hline Participants & $\begin{array}{l}180 \text { homeless adolescents (as per DHHS definition), (14-22 years age, 34\% female) } \\
\text { attending a drop-in centre for homeless youth in a southwestern city in USA, who met } \\
\text { criteria for at least one DSM-IV diagnoses of alcohol or psychoactive substance use } \\
\text { disorder and lived in the area of the study for the preceding three months with intention } \\
\text { to stay in that area for subsequent six months. The ethnicity of participants were: Anglo } \\
\text { (n=73), African American (n=6), Asian (n=1), Hispanic (n=54), native American (n=24) } \\
\text { and other or mixed (n=22). HIV status of participants were not reported. Participants } \\
\text { self identified their sexual orientation as heterosexual (n=147), homosexual (n=4) and } \\
\text { bisexual (n=29). Forty-nine percent of participants had a DSM-IV axis one diagnosis } \\
\text { other than substance abuse or dependence. The HIV status of participants was not } \\
\text { assessed/reported }\end{array}$ \\
\hline $\begin{array}{l}\text { Intervention: Integrated community reinforcement approach (CRA) (a cognitive-be- } \\
\text { havioural approach) and HIV prevention messaging (n=96) }\end{array}$ \\
$\begin{array}{l}\text { Control: Treatment/service as usual (n=84) } \\
\text { Theoretical underpinnings of intervention: }\end{array}$ \\
$\begin{array}{l}\text { The CRA approach is based on an integrated cognitive-behavioural approach that in- } \\
\text { cluded skills building to foster self-efficacy in the practice of preventative behaviours. } \\
\text { The HIV prevention intervention was based on an intervention (Becoming a Responsible } \\
\text { Teen B.A.R.T) covering AIDS education and assessment of risk, risk reduction and } \\
\text { skills practice, sexual assertiveness and practicing negotiation as well as behavioural self- } \\
\text { management and problem-solving strategies } \\
\text { Delivery, dosage and content of intervention } \\
\text { Intervention consisted an integrated set of } 12 \text { CRA sessions and four HIV prevention }\end{array}$ \\
\hline
\end{tabular}




\begin{tabular}{|c|c|c|}
\hline & \multicolumn{2}{|c|}{$\begin{array}{l}\text { sessions. each session lasted about } 50 \text { minutes. The HIV sessions were delivered after the } \\
2^{\text {nd }} \text { CRA session, where convenient the HIV sessions were scheduled in the same week } \\
\text { as the CRA session. The CRA sessions were delivered by trained therapists as follows, } \\
\text { and incorporated role plays and homework : } \\
\text { - Session 1: Rationale for CRA approach explained to adolescent } \\
\text { - Session 2: Development of a tentative treatment plan in active collaboration with } \\
\text { the youth. } \\
\text { - Sessions 3-12: Therapists follow CRA treatment strategies using core procedures } \\
\text { and optional treatment modules based on client needs based on a CRA manual. } \\
\text { The HIV prevention sessions and their content is as follows, and incorporated role-plays: } \\
\text { - Session 1: AIDS education and assessment of risk. Abstinence and other ways at } \\
\text { lowering HIV risk are addressed. } \\
\text { - Session 2: Risk reduction and skills practice including condom use practice on a } \\
\text { model and cleaning hypodermic needles. } \\
\text { - Session 3: Sexual assertiveness including practice of negotiation. in three contexts: } \\
\text { initiating discussion about condoms in advance, refusing pressure to engage in } \\
\text { unprotected sex and refusing pressure to share needles. } \\
\text { - Session } 4 \text { : behavioural self-management and problem solving strategies including } \\
\text { discussion of previous episodes in which the youth conceded to unwanted pressures. } \\
\text { All sessions include role play. } \\
\text { Details on control } \\
\text { Treatment as usual consisted the standard extant care at a homeless persons drop-in centre } \\
\text { including a place to rest during the day, food, showers clothing and case management } \\
\text { that linked youth with community resources at the youth's request }\end{array}$} \\
\hline Outcomes & \multicolumn{2}{|c|}{$\begin{array}{l}\text { HIV risk behaviour assessed at baseline, } 3 \text {-and 6-month post intervention, as composite } \\
\text { score of high-risk behaviours (out of 7), } \\
\text { 1. number of people having sexual intercourse , } \\
\text { 2. frequency of sexual intercourse, } \\
\text { 3. frequency of condom use (ranked on a Likert scale from 1-never to 5-always but } \\
\text { reported as continuous variable), } \\
\text { 4. number engaged in casual sex, } \\
\text { 5. number has sex with more than one partner in last } 24 \text { hours, } \\
\text { 6. number had sex with high risk partner, number engaged in anal sex, } \\
\text { 7. number engaged in survival sex. } \\
\text { Outcomes obtainable from authors and eligible for inclusion in this review were: number } \\
\text { of participants having sexual intercourse, and the frequency of condom use }\end{array}$} \\
\hline \multicolumn{3}{|l|}{ Notes } \\
\hline \multicolumn{3}{|l|}{ Risk of bias } \\
\hline Item & Authors' judgement & Description \\
\hline Adequate sequence generation? & Yes & Urn randomisation \\
\hline Allocation concealment? & Yes & $\begin{array}{l}\text { Central randomisation by project director } \\
\text { communicated to personnel enrolling par- } \\
\text { ticipant }\end{array}$ \\
\hline
\end{tabular}


Slesnick 2008 (Continued)

\begin{tabular}{l|l|l}
\hline $\begin{array}{l}\text { Blinding? } \\
\text { All outcomes }\end{array}$ & No & Unblinded study \\
\hline $\begin{array}{l}\text { Incomplete outcome data addressed? } \\
\text { All outcomes }\end{array}$ & No & $\begin{array}{l}\text { Significant and differential loss to follow } \\
\text { up in two arms at both } 3 \text { month }(31 / 96 \\
\text { in intervention and } 17 / 84 \text { in control arms) } \\
\text { and } 6 \text { month }(15 / 96 \text { in intervention and } \\
10 / 84 \text { in control arms) assessment }\end{array}$ \\
\hline Free of other bias? & No & $\begin{array}{l}\text { Only } 6.8 / 16 \text { sessions attended by partici- } \\
\text { pants on average. } \\
\text { A social networking intervention was con- } \\
\text { current with this trial in the same popu- } \\
\text { lation-it is unclear in what direction this } \\
\text { would have biased the results and whether } \\
\text { the concurrent intervention may have been } \\
\text { differentially affected the two trial arms }\end{array}$ \\
\hline
\end{tabular}

Characteristics of excluded studies [ordered by study ID]

\begin{tabular}{|c|c|}
\hline Study & Reason for exclusion \\
\hline Arnold 2007 & Not a RCT: a cohort of 11 youth $12-15$ years in a feasibility study of strengths based case management \\
\hline Booth 1999 & Not a RCT: a cross-sectional sample of 244 street youth half of whom receive a peer-based intervention \\
\hline Gleghorn 1997 & Not a RCT: pre- and post-assessment of an intervention in 1146 adolescents versus comparison populations \\
\hline Jemmot 2005 & Population inappropriate (not homeless): RCT of HIV/STD risk-reduction in 682 adolescent girls \\
\hline Kidder 2007 & $\begin{array}{l}\text { Population inappropriate. RCT of access to housing among } 630 \text { homeless adults living with HIV/AIDs } \\
\text { with appropriate outcome measures. Included individuals 18-24 (youth)but not analysed separately and } \\
\text { not the primary population }\end{array}$ \\
\hline Lightfoot 2007 & $\begin{array}{l}\text { Population inappropriate (not homeless). RCT of Streetsmart intervention in } 100 \text { youth living with HIV } \\
\text { in Uganda }\end{array}$ \\
\hline Linn 2003 & $\begin{array}{l}\text { Population inappropriate (not adolescents). 'comparison group clinical trial' of a cognitive-behavioural } \\
\text { therapy intervention (SexG) in homeless mentally ill men }\end{array}$ \\
\hline Nyamathi 2001 & $\begin{array}{l}\text { Population inappropriate (not adolescents). A cluster randomised trial of three cognitive-behavioural HIV } \\
\text { risk-reduction in homeless woman ( } 18-50 \text { years) }\end{array}$ \\
\hline Rotheram-Borus 2009 & $\begin{array}{l}\text { Population inappropriate (few adolescents). An RCT of } 936 \text { adults (including } 7 \text { participants } 15-24 \text { years) } \\
\text { of healthy living program vs control for reducing risky sexual behaviour }\end{array}$ \\
\hline
\end{tabular}




\section{Characteristics of ongoing studies [ordered by study ID]}

\section{Nyamathi 2008-11}

\begin{tabular}{|c|c|}
\hline Trial name or title & An Arts Intervention for Drug-Using Homeless Youth \\
\hline Methods & Open-label randomised control trial \\
\hline Participants & $\begin{array}{l}128 \text { male and female unsheltered homeless substance-using youth 15-24 years of age recruited from Common } \\
\text { Ground, Santa Monica, California, USA }\end{array}$ \\
\hline Interventions & $\begin{array}{l}\text { Experimental: Art Messaging: Experimental educational group which utilizes art, photography, film, painting } \\
\text { to portray a message to reduce drug use, and prevent hepatitis A, B, \& C delivered in four sessions } \\
\text { Control: Health Promotion education offering basic information about the prevention of hepatitis A, B \& C } \\
\text { delivered in four sessions }\end{array}$ \\
\hline Outcomes & $\begin{array}{l}\text { Acceptability of the LIFE-MATTERS program, and impact in a subsample of the population (completion } \\
\text { of the program; reduction of risky drug and alcohol use; completion of a HAV/HBV vaccine series; and } \\
\text { improvement in knowledge about hepatitis). [Time Frame: } 2 \text { years] }\end{array}$ \\
\hline Starting date & April 2008 \\
\hline Contact information & $\begin{array}{l}\text { Contact: Adeline Nyamathi, PhD: 310-825-8405; anyamath@sonnet.ucla.edu OR Mary Marfisee, MD: } 310 \text { - } \\
\text { 319-4700; mmarfisee@mednet.ucla.edu }\end{array}$ \\
\hline Notes & $\begin{array}{l}\text { Personal communication with principal investigator suggests that HIV risk behaviour measures are included } \\
\text { in this trial. Due to reach completion in March } 2011\end{array}$ \\
\hline
\end{tabular}

Nyamathi 2009-14

\begin{tabular}{ll}
\hline Trial name or title & Hepatitis B Virus (HBV) Prevention for Homeless at Risk for HBV/Hepatitis C Virus (HCV)/HIV \\
\hline Methods & Open-label randomised control trial \\
\hline Participants & $\begin{array}{l}500 \text { homeless gay or bisexual men 18-39 years of age at Friends community centre, Los Angeles, California, } \\
\text { USA }\end{array}$ \\
\hline Interventions & $\begin{array}{l}\text { Experimental: Nurse Case Management Plus Contingency Management and Tracking and the HBV vaccine } \\
\text { vs Active Control: Standard with Contingency Management and Tracking (SCMT) and HBV vaccine }\end{array}$ \\
\hline Outcomes & $\begin{array}{l}\text { Primary Outcome Measures: Compare the NCMIT and SCMT programs among homeless young gay and } \\
\text { bisexual stimulant using men with respect to completion of a HBV vaccination series administered in three } \\
\text { doses over a four-month period. [Time Frame:5 years] }\end{array}$
\end{tabular}


Secondary Outcome Measures: Document the occurrences of HCV and HIV infections at baseline among these homeless HBV antibody negative stimulant users, and the factors associated with these infections at baseline. [Time Frame:5 years]

\begin{tabular}{ll}
\hline Starting date & July 2009 \\
\hline Contact information & Cathy Reback, PhD: 323-463-1601; reback@friendsresearch.org \\
\hline Notes & Primary population is not youth, but may include youth.Due to reach completion in March 2014 \\
\hline
\end{tabular}

\section{STRIVE 2004-9}

Trial name or title Support To Reunite Involve and Value Each Other (STRIVE): Diverting Homeless Youth From Chronic Homelessness and Risk for HIV

\begin{tabular}{ll}
\hline Methods & Open-label, randomised controlled trial \\
\hline Participants & $\begin{array}{l}302 \text { male and female homeless youth 12-17 years of age recruited through homeless shelters. Location not } \\
\text { provided }\end{array}$ \\
\hline Interventions & $\begin{array}{l}\text { Behavioural: STRIVE family intervention Adolescent and parent attend a 5-session family-oriented cognitive- } \\
\text { behavioural intervention aimed at giving runaway youths and their parents the tools to effectively deal with } \\
\text { conflict }\end{array}$ \\
\hline Outcomes & $\begin{array}{l}\text { Primary Outcome Measures: Improved residential stability [Time Frame:Assessed up to 24 months] } \\
\text { Secondary Outcome Measures: Reduced HIV risk behaviour [Time Frame: Up to 24 months] }\end{array}$ \\
\hline Starting date & September 2004 \\
\hline Contact information & Norweeta Milburn, PhD, UCLA Center for Community Health, NMilburn@mednet.ucla.edu \\
\hline Notes & Study completed June 2009, but data not yet available at time of review \\
\hline
\end{tabular}


DATA AND ANALYSES

This review has no analyses.

A P PENDICES

Appendix I. AIDSSEARCH search strategy

Database:

AIDSearch $1980-2008$

Date:

1 August 2008

\begin{tabular}{|c|c|c|}
\hline Set\# & Search Strategy & Matches \\
\hline$\# 1$ & $\begin{array}{l}\text { (HIV INFECTIONS) OR HIV OR HIV OR HIV-1* OR } \\
\text { HIV-2* OR HIV1 OR HIV2 OR (HIV INFECT*) OR (HU- } \\
\text { MAN IMMUNODEFICIENCY VIRUS) OR (HUMAN } \\
\text { IMMUNEDEFICIENCY VIRUS) OR (HUMAN IM- } \\
\text { MUNO-DEFICIENCY VIRUS) OR (HUMAN IMMUNE- } \\
\text { DEFICIENCY VIRUS) OR ((HUMAN IMMUN*) AND } \\
\text { (DEFICIENCY VIRUS)) OR (ACQUIRED IMMUNODE- } \\
\text { FICIENCY SYNDROME) OR (ACQUIRED IMMUNED- } \\
\text { EFICIENCY SYNDROME) OR (ACQUIRED IMMUNO- } \\
\text { DEFICIENCY SYNDROME) OR (ACQUIRED IM- } \\
\text { MUNE-DEFICIENCY SYNDROME) OR ((ACQUIRED } \\
\text { IMMUN*) AND (DEFICIENCY SYNDROME)) OR (SEX- } \\
\text { UALLY TRANSMITTED DISEASES, VIRAL) }\end{array}$ & 312,822 \\
\hline$\# 2$ & $\begin{array}{l}\text { ((RANDOMIZED CONTROLLED TRIAL) OR (CON- } \\
\text { TROLLED CLINICAL TRIAL) OR (RANDOMIZED } \\
\text { CONTROLLED TRIALS) OR (RANDOM ALLOCA- } \\
\text { TION) OR (DOUBLE-BLIND METHOD) OR (SIN- } \\
\text { GLE-BLIND METHOD) OR (CLINICAL TRIAL) OR } \\
\text { (CLINICAL TRIALS) OR ("CLINICAL TRIAL“) OR ( } \\
\text { (SINGL* OR DOUBL* OR TREBL* OR TRIPL* AND } \\
\text { (MASK* OR BLIND*)) OR PLACEBOS OR PLACEBO* } \\
\text { OR RANDOM* OR (COMPARATIVE STUDY) OR } \\
\text { (EVALUATION STUDIES) OR (FOLLOW-UP STUD- } \\
\text { IES) OR (PROSPECTIVE STUDIES) OR CONTROL*OR } \\
\text { PROSPECTIV* OR VOLUNTEER*)) NOT (ANIMALS } \\
\text { NOT HUMAN) }\end{array}$ & 181,184 \\
\hline \#3 & \#1 AND \#2 & 127,212 \\
\hline
\end{tabular}


\#4 (RISK REDUCTION BEHAVIOR) OR (RISK REDUC5,796

TION BEHAVIORS) OR (RISK REDUCTION BEHAVIOUR) OR (RISK REDUCTION BEHAVIOURS) OR (BEHAVIOR, RISK REDUCTION) OR (BEHAVIORS, RISK REDUCTION) OR (LIFESTYLE RISK REDUCTION) OR (LIFESTYLE RISK REDUCTIONS) OR (RISK REDUCTIONS) OR (RISK REDUCING BEHAVIOR) OR (RISK REDUCING BEHAVIOUR) OR (RISK REDUCING BEHAVIORS) OR (RISK REDUCING BEHABVIOURS) OR (SEXUAL RISK BEHAVIOR) OR (SEXUAL RISK BEHAVIOUR) OR (SEXUAL RISK BEHAVIORS) OR (SEXUAL RISK BEHAVIOURS) OR (SEXUAL RISK REDUCTION)

\begin{tabular}{ll} 
\#5 & \#3 AND \#4 \\
\hline \#6 & (HOMELESS YOUTHS) OR (YOUTH, HOMELESS) OR \\
(YOUTHS, HOMELESS) OR (HOMELESS CHILD) OR \\
(CHILD, HOMELESS) OR (HOMELESS CHILDREN) \\
OR (CHILDREN, HOMELESS) OR (STREET YOUTH) \\
OR (YOUTH, STREET) OR (YOUTHS, STREET) OR \\
RUNAWAYS OR RUNAWAY OR (STREET CHILDREN) \\
OR (CHILDREN, STREET) OR (STREET CHILD) OR \\
(CHILD, STREET)
\end{tabular}

\section{Appendix 2. CENTRAL search strategy}

\section{Database: $\quad$ CENTRAL: Cochrane Library}

1 August 2008

11 Trials retrieved

\begin{tabular}{ll|l}
\hline ID & Search & Hits \\
\hline$\# 1$ & $\begin{array}{l}\text { (HIV INFECTIONS) OR HIV OR HIV OR HIV- } \\
1^{*} \text { OR HIV-2* OR HIV1 OR HIV2 OR (HIV }\end{array}$ & 7853 \\
& $\begin{array}{l}\text { INFECT*) OR (HUMAN IMMUNODEFICIENCY } \\
\text { VIRUS) OR (HUMAN IMMUNEDEFICIENCY } \\
\text { VIRUS) OR (HUMAN IMMUNO-DEFICIENCY }\end{array}$ & \\
&
\end{tabular}


VIRUS) OR (HUMAN IMMUNE-DEFICIENCY

VIRUS) OR ((HUMAN IMMUN*) AND

(DEFICIENCY VIRUS)) OR (ACQUIRED

IMMUNODEFICIENCY SYNDROME) OR

(ACQUIRED IMMUNEDEFICIENCY SYNDROME)

OR (ACQUIRED IMMUNO-DEFICIENCY

SYNDROME) OR (ACQUIRED IMMUNE-

DEFICIENCY SYNDROME) OR ((ACQUIRED

IMMUN*) AND (DEFICIENCY SYNDROME)) OR

(VIRAL SEXUALLY TRANSMITTED DISEASES)

\#2 (RISK REDUCTION BEHAVIOR) OR (RISK

14774

REDUCTION BEHAVIORS) OR (RISK REDUCTION

BEHAVIOUR) OR (RISK REDUCTION

BEHAVIOURS) OR (RISK REDUCTION BEHAVIOR)

OR (RISK REDUCTION BEHAVIORS) OR

(LIFESTYLE RISK REDUCTION) OR (LIFESTYLE

RISK REDUCTIONS) OR (RISK REDUCTIONS)

OR (RISK REDUCING BEHAVIOR) OR (RISK

REDUCING BEHAVIOUR) OR (RISK REDUCING

BEHAVIORS) OR (RISK REDUCING BEHABVIOURS)

OR (SEXUAL RISK BEHAVIOR) OR (SEXUAL RISK

BEHAVIOUR) OR (SEXUAL RISK BEHAVIORS) OR

(SEXUAL RISK BEHAVIOURS) OR (SEXUAL RISK

REDUCTION)

\#3 (HOMELESS YOUTHS) OR (HOMELESS YOUTH)

OR (HOMELESS CHILD) OR (HOMELESS

CHILDREN) OR (STREET YOUTH) OR (STREET

YOUTHS) OR RUNAWAYS OR RUNAWAY OR

(STREET CHILDREN) OR (STREET CHILD)

Date:

13 January 2010

Number of clinical trials retrieved:

4 records 


\begin{tabular}{|c|c|c|}
\hline ID & Search & Hits \\
\hline$\# 1$ & MeSH descriptor HIV Infections explode all trees & 5850 \\
\hline \#2 & MeSH descriptor HIV explode all trees & 1828 \\
\hline \#3 & $\begin{array}{l}\text { hiv OR hiv-1* OR hiv-2* OR hiv1 OR hiv2 OR HIV } \\
\text { INFECT* OR HUMAN IMMUNODEFICIENCY } \\
\text { VIRUS OR HUMAN IMMUNEDEFICIENCY VIRUS } \\
\text { OR HUMAN IMMUNE-DEFICIENCY VIRUS } \\
\text { OR HUMAN IMMUNO-DEFICIENCY VIRUS } \\
\text { OR HUMAN IMMUN* DEFICIENCY VIRUS OR } \\
\text { ACQUIRED IMMUNODEFICIENCY SYNDROME } \\
\text { OR ACQUIRED IMMUNEDEFICIENCY SYNDROME } \\
\text { OR ACQUIRED IMMUNO-DEFICIENCY } \\
\text { SYNDROME OR ACQUIRED IMMUNE- } \\
\text { DEFICIENCY SYNDROME OR ACQUIRED IMMUN* } \\
\text { DEFICIENCY SYNDROME }\end{array}$ & 8658 \\
\hline \#4 & MeSH descriptor Lymphoma, AIDS-Related, this term only & 21 \\
\hline \#5 & $\begin{array}{l}\text { MeSH descriptor Sexually Transmitted Diseases, Viral, this } \\
\text { term only }\end{array}$ & 17 \\
\hline \#6 & (\#1 OR \#2 OR \#3 OR \#4 OR \#5) & 8790 \\
\hline \#7 & $\begin{array}{l}\text { (RISK REDUCTION BEHAVIOR) OR (RISK } \\
\text { REDUCTION BEHAVIORS) OR (RISK REDUCTION } \\
\text { BEHAVIOUR) OR (RISK REDUCTION } \\
\text { BEHAVIOURS) OR (RISK REDUCTION BEHAVIOR) } \\
\text { OR (RISK REDUCTION BEHAVIORS) OR } \\
\text { (LIFESTYLE RISK REDUCTION) OR (LIFESTYLE } \\
\text { RISK REDUCTIONS) OR (RISK REDUCTIONS) } \\
\text { OR (RISK REDUCING BEHAVIOR) OR } \\
\text { (RISK REDUCING BEHAVIOUR) OR (RISK } \\
\text { REDUCING BEHAVIORS) OR (RISK REDUCING } \\
\text { BEHABVIOURS) OR (SEXUAL RISK BEHAVIOR) } \\
\text { OR (SEXUAL RISK BEHAVIOUR) OR (SEXUAL RISK } \\
\text { BEHAVIORS) OR (SEXUAL RISK BEHAVIOURS) OR } \\
\text { (SEXUAL RISK REDUCTION) }\end{array}$ & 16852 \\
\hline \#8 & $\begin{array}{l}\text { (HOMELESS YOUTHS) OR (HOMELESS YOUTH) } \\
\text { OR (HOMELESS CHILD) OR (HOMELESS } \\
\text { CHILDREN) OR (STREET YOUTH) OR (STREET } \\
\text { YOUTHS) OR RUNAWAYS OR RUNAWAY OR } \\
\text { (STREET CHILDREN) OR (STREET CHILD) }\end{array}$ & 970 \\
\hline \#9 & (\#6 AND \#7 AND \#8) & 67 \\
\hline
\end{tabular}


Appendix 3. EMBASE search strategy

Database:

EMBASE $1980-2008$

Date:

8 August 2008

\begin{tabular}{|c|c|c|c|}
\hline No. & Query & Results & Date \\
\hline$\# 1$ & $\begin{array}{l}\text { ('human immunodeficiency virus in- } \\
\text { fection'/exp OR 'human immunode- } \\
\text { ficiency virus infection') OR (('hu- } \\
\text { man immunodeficiency virus'/exp OR } \\
\text { 'human immunodeficiency virus')) } \\
\text { OR ((('b cell lymphoma'/de OR 'b } \\
\text { cell lymphoma') OR ('b cell lym- } \\
\text { phoma'/de OR 'b cell lymphoma'))) } \\
\text { ) OR (hiv:ti OR hiv:ab) OR ('hiv-1': } \\
\text { ti OR 'hiv-1':ab) OR ('hiv-2':ti OR } \\
\text { 'hiv-2':ab) OR ('human immunodefi- } \\
\text { ciency virus':ti OR 'human immun- } \\
\text { odeficiency virus':ab) OR ('human } \\
\text { immunedeficiency virus':ti OR 'hu- } \\
\text { man immunedeficiency virus':ab) OR } \\
\text { ('human immune-deficiency virus':ti } \\
\text { OR'human immune-deficiency virus': } \\
\text { ab) OR ('human immuno-deficiency } \\
\text { virus':ti OR 'human immuno-defi- } \\
\text { ciency virus':ab) OR ('acquired im- } \\
\text { munodeficiency syndrome':ti OR 'ac- } \\
\text { quired immunodeficiency syndrome': } \\
\text { ab) OR ('acquired immuno-deficiency } \\
\text { syndrome':ti OR 'acquired immuno- } \\
\text { deficiency syndrome':ab) OR ('ac- } \\
\text { quired immune-deficiency syndrome': } \\
\text { ti OR 'acquired immune-deficiency } \\
\text { syndrome':ab) OR ('acquired im- } \\
\text { munedeficiency syndrome':ti OR 'ac- } \\
\text { quired immunedeficiency syndrome': } \\
\text { ab) }\end{array}$ & 295,230 & 08 Aug 2008 \\
\hline
\end{tabular}


((random*:ti OR random*:ab) OR

812,706 08 Aug 2008

(factorial*:ti OR factorial*:ab) OR

(cross?over*:ti OR cross?over*:ab OR crossover*:ti OR crossover*:ab) OR (placebo*:ti OR placebo*:ab) OR ( (doubl*:ti AND blind*:ti) OR (doubl*: ab AND blind*:ab)) OR ((singl*:ti AND blind*:ti) OR (singl*:ab AND blind*:ab)) OR (assign*:ti OR assign*: ab) OR (allocat*:ti OR allocat*:ab) OR (volunteer*:ti OR volunteer*:ab) OR (('crossover procedure'/exp OR 'crossover procedure') OR ('crossover procedure'/de OR 'crossover procedure'))) OR (('double-blind procedure'/exp OR 'double-blind procedure') OR ('double-blind procedure'/ de OR 'double-blind procedure'))) OR (('single-blind procedure'/exp OR 'single-blind procedure') OR ('singleblind procedure'/de OR 'single-blind procedure'))) OR ((('randomised controlled trial'/exp OR 'randomised controlled trial') OR ('randomised controlled trial'/de OR 'randomised controlled trial'))))

\#3 ('risk reduction behavior'/de OR 'risk 28,578 08 Aug 2008 reduction behavior') $O R$ 'risk reduction behaviors' $O R$ 'risk reduction behaviour' OR 'risk reduction behaviours' $O R$ 'behavior, risk reduction' $O R$ 'behaviors, risk reduction' OR 'lifestyle risk reduction' OR 'lifestyle risk reductions' OR 'risk reductions' OR 'risk reducing behavior' OR 'risk reducing behaviour' OR 'risk reducing behaviors' $O R$ 'risk reducing behabviours' $O R$ 'sexual risk behavior' OR 'sexual risk behaviour' $O R$ 'sexual risk behaviors' $O R$ 'sexual risk behaviours' OR 'sexual risk reduction' OR ('risk reduction'/de OR 'risk reduction')

\#4 'homeless youths' OR 'youth, homeless' OR 'youths, homeless' OR 'homeless child' $O R$ 'child, homeless' $O R$ 'homeless children' OR 'children, 
homeless' OR 'street youth' OR 'youth, street' $O R$ 'youths, street' $O R$ ('runaways'/de OR 'runaways') OR runaway $O R$ 'street children' $O R$ 'children, street' $O R$ 'street child' $O R$ 'child, street' OR ('homelessness'/de OR 'homelessness') OR ('runaway behavior'/de OR 'runaway behavior')

\#5 \#1 AND \#2 AND \#3 AND \#4 AND $7 \quad 08$ Aug 2008
[1980-2008]/py

Database:

EMBASE $2008-2010$

Date: $\quad 13$ January 2010

\begin{tabular}{ll|l|l}
\hline No. & Query & Results & Date \\
\hline \#6 & $\begin{array}{l}\text { \#1 AND \#2 AND \#3 AND \#4 AND } \\
{[\text { humans]/lim AND [embase]/lim AND }} \\
{[2008-2010] / \text { py }}\end{array}$ & 13 Jan 2010 \\
\hline \#5 & \#1 AND \#2 AND \#3 AND \#4 & 11 & 13 Jan 2010 \\
\hline \#4 & $\begin{array}{l}\text { 'homeless youths' OR 'youth, homeless' } \\
\text { OR 'youths, homeless' OR 'homeless } \\
\text { child' OR 'child, homeless' OR 'home- } \\
\text { less children' OR 'children, homeless' } \\
\text { OR 'street youth' OR 'youth, street' OR } \\
\text { 'youths, street' OR 'runaways'/de OR } \\
\text { 'runaways' OR runaway OR 'street chil- } \\
\text { dren' OR 'children, street' OR 'street } \\
\text { child' OR 'child, street' OR 'homeless- } \\
\text { ness'/de OR 'homelessness' OR'runaway } \\
\text { behavior'/de OR 'runaway behavior' }\end{array}$ & 13 Jan 2010 \\
\hline \#3 & $\begin{array}{l}\text { 'risk reduction behavior'/de OR 'risk re- } \\
\text { duction behavior' OR 'risk reduction be- } \\
\text { haviors' OR 'risk reduction behaviour' } \\
\text { OR 'risk reduction behaviours' OR 'be- } \\
\text { havior, risk reduction' OR 'behaviors, } \\
\text { risk reduction' OR 'lifestyle risk reduc- } \\
\text { tion' OR 'lifestyle risk reductions' OR }\end{array}$ & 13 Jan 2010 \\
\hline
\end{tabular}


'risk reductions' OR 'risk reducing behavior' OR 'risk reducing behaviour' OR 'risk reducing behaviors' OR 'risk reducing behabviours' OR 'sexual risk behavior' OR 'sexual risk behaviour' OR 'sexual risk behaviors' OR 'sexual risk behaviours' OR 'sexual risk reduction' OR 'risk reduction'/de OR 'risk reduction'

\#2 random*:ti OR random*:ab OR factorial* $^{*}$ :ti OR factorial ${ }^{*}$ :ab OR cross?over* ${ }^{*}$ : ti OR cross?over:ab OR crossover*:ti OR crossover*:ab OR placebo*:ti OR placebo*:ab OR (doubl*:ti AND blind*: ti) OR (doubl*:ab AND blind*:ab) OR (singl*:ti AND blind*:ti) OR (singl*: ab AND blind*:ab) OR assign*:ti OR assign*:ab OR volunteer*:ti OR volunteer*:ab OR 'crossover procedure'/de OR 'crossover procedure' OR 'doubleblind procedure'/de OR 'double-blind procedure' OR 'single-blind procedure'/ de OR 'single-blind procedure' OR 'randomised controlled trial'/de OR 'randomised controlled trial' OR allocat*:ti OR allocat*ab

\#1 'human immunodeficiency virus in- 319996

13 Jan 2010 fection'/exp OR 'human immunodeficiency virus infection' $O R$ 'human immunodeficiency virus'/exp OR 'human immunodeficiency virus' OR 'b cell lymphoma'/de OR 'b cell lymphoma' OR hiv:ti OR hiv:ab OR 'hiv1':ti OR 'hiv-1':ab OR 'hiv-2':ti OR 'hiv-2':ab OR 'human immunodeficiency virus':ti OR 'human immunodeficiency virus':ab OR 'human immunedeficiency virus' :ti OR 'human immunedeficiency virus':ab OR 'human immunedeficiency virus':ti OR 'human immunedeficiency virus':ab OR 'human immuno-deficiency virus':ti OR 'human immuno-deficiency virus':ab OR 'acquired immunodeficiency syndrome':ti OR 'acquired immunodeficiency syndrome':ab OR 'acquired immuno-deficiency syndrome':ti OR 'acquired immuno-deficiency syndrome':ab OR 'ac- 
quired immune-deficiency syndrome':ti OR 'acquired immune-deficiency syndrome':ab OR 'acquired immunedeficiency syndrome':ti OR 'acquired immunedeficiency syndrome':ab

\section{Appendix 4. Gateway search strategy}

\section{Database: $\quad$ GATEWAY 1980 - 2008}

Date:

4 August 2008

Meeting Abstracts: 34 records

\begin{tabular}{|c|c|c|}
\hline $\begin{array}{l}\text { Search } \\
\text { Number }\end{array}$ & Search & $\begin{array}{l}\text { Items } \\
\text { Found }\end{array}$ \\
\hline \#6 & $\begin{array}{l}\text { Search: } \\
(((\text { ”HIV Infections“[MeSH] OR "HIV“[MeSH] OR } \\
\text { hiv [tw] OR hiv-1*[tw] OR hiv-2*[tw] OR hiv1[tw] } \\
\text { OR hiv2[tw] OR hiv infect*[tw] OR human immun- } \\
\text { odeficiency virus[tw] OR human immunedeficiency } \\
\text { virus[tw] OR human immuno-deficiency virus[tw] OR } \\
\text { human immune-deficiency virus[tw] OR ((human im- } \\
\text { mun*) AND (deficiency virus[tw])))) OR ((acquired } \\
\text { immunodeficiency syndrome[tw] OR acquired im- } \\
\text { munedeficiency syndrome[tw] OR acquired immuno- } \\
\text { deficiency syndrome[tw] OR acquired immune-defi- } \\
\text { ciency syndrome[tw] OR ((acquired immun*) AND } \\
\text { (deficiency syndrome[tw])) OR "Sexually Transmitted } \\
\text { Diseases, Viral“[MeSH:NoExp]))) AND (((randomised } \\
\text { controlled trial [pt] OR controlled clinical trial [pt] OR } \\
\text { randomised controlled trials [mh] OR random alloca- } \\
\text { tion [mh] OR double-blind method [mh] OR single- } \\
\text { blind method [mh] OR clinical trial [pt] OR clinical } \\
\text { trials [mh] OR ("clinical trial“ [tw]) OR ((singl* [tw] } \\
\text { OR doubl* [tw] OR trebl* [tw] OR tripl* [tw]) AND } \\
\text { (mask* [tw] OR blind* [tw])))) OR (( placebos [mh] } \\
\text { OR placebo* [tw] OR random* [tw] OR research de- } \\
\text { sign [mh:noexp] OR comparative study [mh] OR eval- } \\
\text { uation studies [mh] OR follow-up studies [mh] OR }\end{array}$ & 176 \\
\hline
\end{tabular}


prospective studies [mh] OR control* [tw] OR prospectiv* $^{*}$ tw] OR volunteer* [tw]) NOT (animals [mh] NOT human $[\mathrm{mh}]))))$ AND ((RISK REDUCTION BEHAVIOR) OR (RISK REDUCTION BEHAVIORS) OR (RISK REDUCTION BEHAVIOUR) OR (RISK REDUCTION BEHAVIOURS) OR (BEHAVIOR, RISK REDUCTION) OR (BEHAVIORS, RISK REDUCTION) OR (LIFESTYLE RISK REDUCTION) OR (LIFESTYLE RISK REDUCTIONS) OR (RISK REDUCTIONS)) OR ((RISK REDUCING BEHAVIOR) OR (RISK REDUCING BEHAVIOUR) OR (RISK REDUCING BEHAVIORS) OR (RISK REDUCING BEHABVIOURS) OR (SEXUAL RISK BEHAVIOR) OR (SEXUAL RISK BEHAVIOUR) OR (SEXUAL RISK BEHAVIORS) OR (SEXUAL RISK BEHAVIOURS) OR (SEXUAL RISK REDUCTION) )) AND ((HOMELESS YOUTHS) OR (YOUTH, HOMELESS) OR (YOUTHS, HOMELESS) OR (HOMELESS CHILD) OR (CHILD, HOMELESS) OR (HOMELESS CHILDREN) OR (CHILDREN, HOMELESS) OR (STREET YOUTH) OR (YOUTH, STREET) OR (YOUTHS, STREET) OR RUNAWAYS OR RUNAWAY OR (STREET CHILDREN) OR (CHILDREN, STREET) OR (STREET CHILD) OR (CHILD, STREET)) Limit: 1980:2008

\#5

Search: (HOMELESS YOUTHS) OR (YOUTH, 19146 HOMELESS) OR (YOUTHS, HOMELESS) OR (HOMELESS CHILD) OR (CHILD, HOMELESS) OR (HOMELESS CHILDREN) OR (CHILDREN, HOMELESS) OR (STREET YOUTH) OR (YOUTH, STREET) OR (YOUTHS, STREET) OR RUNAWAYS OR RUNAWAY OR (STREET CHILDREN) OR (CHILDREN, STREET) OR (STREET CHILD) OR (CHILD, STREET)

((("HIV Infections"[MeSH] OR "HIV" [MeSH] OR hiv [tw] OR hiv-1*[tw] OR hiv-2*[tw] OR hiv1[tw] OR hiv2[tw] OR hiv infect*[tw] OR human immunodeficiency virus $[\mathrm{tw}]$ OR human immunedeficiency virus [tw] OR human immuno-deficiency virus[tw] OR human immune-deficiency virus[tw] OR ((human immun*) AND (deficiency virus[tw])))) OR ((acquired immunodeficiency syndrome[tw] OR acquired immunedeficiency syndrome[tw] OR acquired immunodeficiency syndrome[tw] OR acquired immune-deficiency syndrome[tw] OR ((acquired immun*) AND (deficiency syndrome[tw])) OR "Sexually Transmitted 
Diseases, Viral“[MeSH:NoExp]))) AND (((randomised controlled trial $[\mathrm{pt}]$ OR controlled clinical trial $[\mathrm{pt}] \mathrm{OR}$ randomised controlled trials [mh] OR random allocation [mh] OR double-blind method [mh] OR singleblind method [mh] OR clinical trial [pt] OR clinical trials [mh] OR ("clinical trial" [tw]) OR ((singl* [tw] OR doubl* [tw] OR trebl* [tw] OR tripl* [tw]) AND $\left(\right.$ mask* $^{*}$ tw] OR blind* [tw] $\left.\left.)\right)\right)$ OR $((($ placebos $[\mathrm{mh}]$ OR placebo* [tw] OR random* [tw] OR research design [mh:noexp] OR comparative study [mh] OR evaluation studies [mh] OR follow-up studies [mh] OR prospective studies [mh] OR control* [tw] OR prospectiv* [tw] OR volunteer* [tw]) NOT (animals [mh] NOT human $[\mathrm{mh}]))))$ AND (((RISK REDUCTION BEHAVIOR) OR (RISK REDUCTION BEHAVIORS) OR (RISK REDUCTION BEHAVIOUR) OR (RISK REDUCTION BEHAVIOURS) OR (BEHAVIOR, RISK REDUCTION) OR (BEHAVIORS, RISK REDUCTION) OR (LIFESTYLE RISK REDUCTION) OR (LIFESTYLE RISK REDUCTIONS) OR (RISK REDUCTIONS)) OR ((RISK REDUCING BEHAVIOR) OR (RISK REDUCING BEHAVIOUR) OR (RISK REDUCING BEHAVIORS) OR (RISK REDUCING BEHABVIOURS) OR (SEXUAL RISK BEHAVIOR) OR (SEXUAL RISK BEHAVIOUR) OR (SEXUAL RISK BEHAVIORS) OR (SEXUAL RISK BEHAVIOURS) OR (SEXUAL RISK REDUCTION) ) ) (RISK REDUCTION BEHAVIORS) OR (RISK REDUCTION BEHAVIOUR) OR (RISK REDUCTION BEHAVIOURS) OR (BEHAVIOR, RISK REDUCTION) OR (BEHAVIORS, RISK REDUCTION) OR (LIFESTYLE RISK REDUCTION) OR (LIFESTYLE RISK REDUCTIONS) OR (RISK REDUCTIONS)) OR ((RISK REDUCING BEHAVIOR) OR (RISK REDUCING BEHAVIOUR) OR (RISK REDUCING BEHAVIORS) OR (RISK REDUCING BEHAVIOURS) OR (SEXUAL RISK BEHAVIOR) OR (SEXUAL RISK BEHAVIOUR) OR (SEXUAL RISK BEHAVIORS) OR (SEXUAL RISK BEHAVIOURS) OR (SEXUAL RISK REDUCTION) ) trolled clinical trial $[\mathrm{pt}]$ OR randomised controlled trials [mh] OR random allocation [mh] OR double-blind method [mh] OR single-blind method [mh] OR clini- 


\begin{tabular}{|c|c|c|}
\hline & $\begin{array}{l}\text { cal trial [pt] OR clinical trials [mh] OR ("clinical trial“ } \\
\text { [tw]) OR ((singl* [tw] OR doubl* [tw] OR trebl* [tw] } \\
\text { OR tripl* [tw]) AND (mask* [tw] OR blind* [tw])))) } \\
\text { OR ((( placebos [mh] OR placebo* [tw] OR random* } \\
\text { [tw] OR research design [mh:noexp] OR comparative } \\
\text { study [mh] OR evaluation studies [mh] OR follow-up } \\
\text { studies [mh] OR prospective studies [mh] OR control* } \\
\text { [tw] OR prospectiv* [tw] OR volunteer* [tw]) NOT } \\
\text { (animals [mh] NOT human [mh]))) }\end{array}$ & \\
\hline$\# 1$ & $\begin{array}{l}\text { Search: (("HIV Infections"[MeSH] OR "HIV“[MeSH] } \\
\text { OR hiv [tw] OR hiv-1*[tw] OR hiv-2*[tw] OR hiv1[tw] } \\
\text { OR hiv2[tw] OR hiv infect*[tw] OR human immun- } \\
\text { odeficiency virus[tw] OR human immunedeficiency } \\
\text { virus[tw] OR human immuno-deficiency virus[tw] OR } \\
\text { human immune-deficiency virus[tw] OR ((human im- } \\
\text { mun*) AND (deficiency virus[tw])))) OR ((acquired } \\
\text { immunodeficiency syndrome[tw] OR acquired im- } \\
\text { munedeficiency syndrome[tw] OR acquired immuno- } \\
\text { deficiency syndrome[tw] OR acquired immune-defi- } \\
\text { ciency syndrome[tw] OR ((acquired immun*) AND } \\
\text { (deficiency syndrome[tw])) OR "Sexually Transmitted } \\
\text { Diseases, Viral“[MeSH:NoExp])) }\end{array}$ & 338435 \\
\hline
\end{tabular}

Date: 13 January 2010

Meeting Abstracts Retrieved: None

\begin{tabular}{l|l|l}
\hline $\begin{array}{l}\text { Search } \\
\text { Number }\end{array}$ & Search & $\begin{array}{l}\text { Items } \\
\text { Found }\end{array}$ \\
\hline$\# 6$ & $\begin{array}{l}\text { Search: (("HIV Infections“[MeSH] OR "HIV“[MeSH] } \\
\text { OR hiv [tw] OR hiv-1*[tw] OR hiv-2*[tw] OR hiv1[tw] } \\
\text { OR hiv2[tw] OR hiv infect*[tw] OR human immun- } \\
\text { odeficiency virus[tw] OR human immunedeficiency } \\
\text { virus[tw] OR human immuno-deficiency virus[tw] OR } \\
\text { human immune-deficiency virus[tw]) OR ((human } \\
\text { immun*) AND (deficiency virus[tw]) OR acquired } \\
\text { immunodeficiency syndrome[tw] OR acquired im- } \\
\text { munedeficiency syndrome[tw] OR acquired immuno- } \\
\text { deficiency syndrome[tw] OR acquired immune-defi- } \\
\text { ciency syndrome[tw] OR ((acquired immun*) AND }\end{array}$ \\
\hline
\end{tabular}


(deficiency syndrome[tw])) OR "Sexually Transmitted Diseases, Viral"[MeSH:NoExp])) AND ((randomised controlled trial OR controlled clinical trial OR randomised OR placebo OR drug therapy OR randomly OR trial OR groups) NOT (animals [mh] NOT humans $[\mathrm{mh}]))$ AND (((RISK REDUCTION BEHAVIOR) OR (RISK REDUCTION BEHAVIORS) OR (RISK REDUCTION BEHAVIOUR) OR (RISK REDUCTION BEHAVIOURS) OR (BEHAVIOR, RISK REDUCTION) OR (BEHAVIORS, RISK REDUCTION) OR (LIFESTYLE RISK REDUCTION) OR (LIFESTYLE RISK REDUCTIONS) OR (RISK REDUCTIONS) OR (RISK REDUCING BEHAVIOR) ) OR ((RISK REDUCING BEHAVIOUR) OR (RISK REDUCING BEHAVIORS) OR (RISK REDUCING BEHABVIOURS) OR (SEXUAL RISK BEHAVIOR) OR (SEXUAL RISK BEHAVIOUR) OR (SEXUAL RISK BEHAVIORS) OR (SEXUAL RISK BEHAVIOURS) OR (SEXUAL RISK REDUCTION) )) AND (((HOMELESS YOUTHS) OR (YOUTH, HOMELESS) OR (YOUTHS, HOMELESS) OR (HOMELESS CHILD) OR (CHILD, HOMELESS) OR (HOMELESS CHILDREN) OR (CHILDREN, HOMELESS) OR (STREET YOUTH) OR (YOUTH, STREET) OR (YOUTHS, STREET)) OR (RUNAWAYS OR RUNAWAY OR (STREET CHILDREN) OR (CHILDREN, STREET) OR (STREET CHILD) OR (CHILD, STREET))) Limit: 2008/07/01:2010/ $01 / 13$ OR hiv [tw] OR hiv-1*[tw] OR hiv-2*[tw] OR hiv1 [tw] OR hiv2[tw] OR hiv infect*[tw] OR human immunodeficiency virus[tw] OR human immunedeficiency virus[tw] OR human immuno-deficiency virus[tw] OR human immune-deficiency virus[tw]) OR ((human immun*) AND (deficiency virus[tw])) OR acquired immunodeficiency syndrome[tw] OR acquired immunedeficiency syndrome[tw] OR acquired immunodeficiency syndrome[tw] OR acquired immune-deficiency syndrome[tw] OR ((acquired immun*) AND (deficiency syndrome[tw])) OR "Sexually Transmitted Diseases, Viral“[MeSH:NoExp])) AND ((randomised controlled trial OR controlled clinical trial OR randomised OR placebo OR drug therapy OR randomly OR trial OR groups) NOT (animals [mh] NOT humans $[\mathrm{mh}]))$ AND (((RISK REDUCTION BEHAVIOR) OR (RISK REDUCTION BEHAVIORS) OR (RISK REDUCTION BEHAVIOUR) OR (RISK RE- 


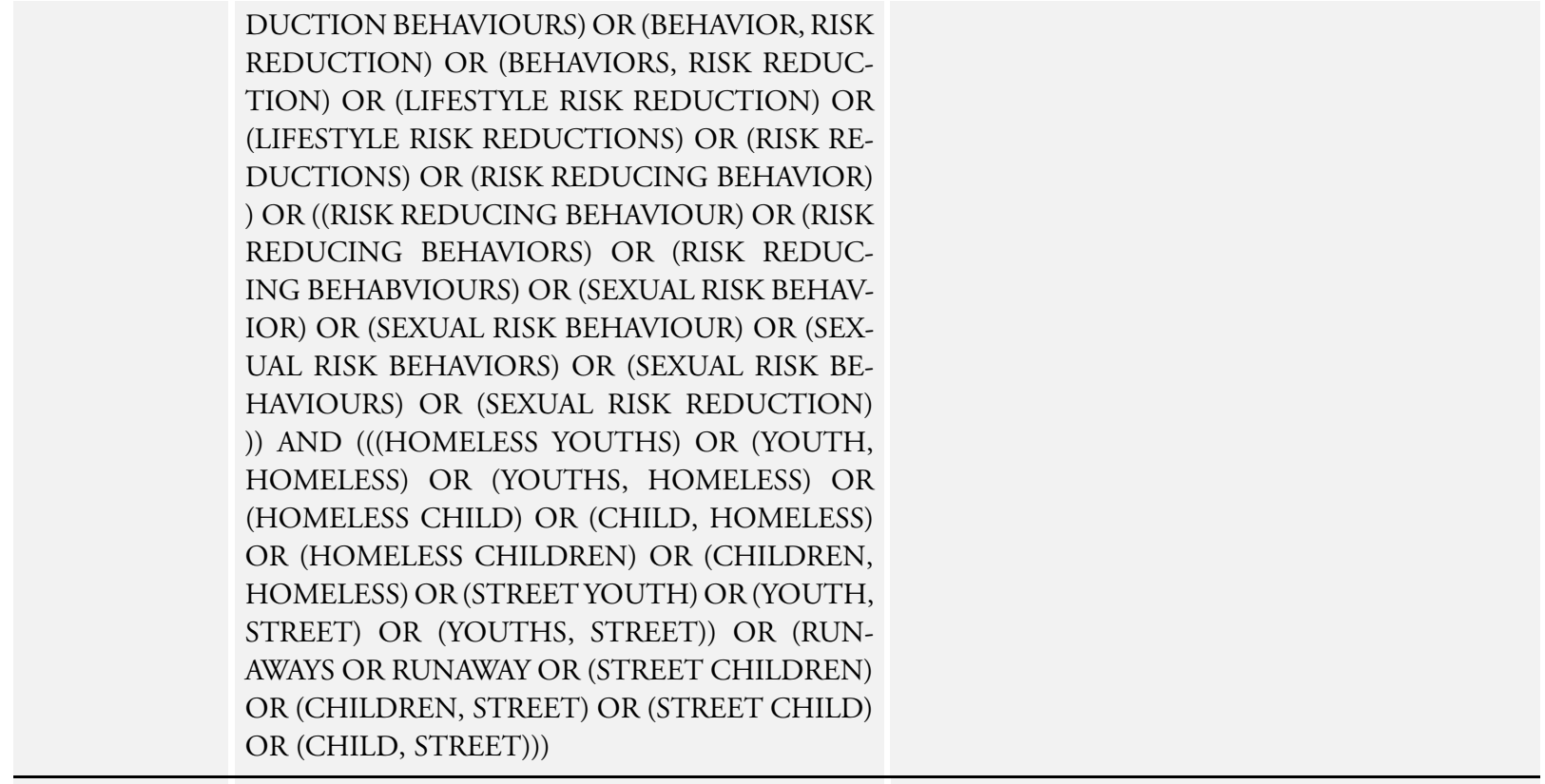

\#4

Search: ((HOMELESS YOUTHS) OR (YOUTH, 21829

HOMELESS) OR (YOUTHS, HOMELESS) OR

(HOMELESS CHILD) OR (CHILD, HOMELESS)

OR (HOMELESS CHILDREN) OR (CHILDREN, HOMELESS) OR (STREET YOUTH) OR (YOUTH, STREET) OR (YOUTHS, STREET)) OR (RUNAWAYS OR RUNAWAY OR (STREET CHILDREN) OR (CHILDREN, STREET) OR (STREET CHILD) OR (CHILD, STREET))

\#3

Search: ((RISK REDUCTION BEHAVIOR) OR 56243

(RISK REDUCTION BEHAVIORS) OR (RISK REDUCTION BEHAVIOUR) OR (RISK REDUCTION BEHAVIOURS) OR (BEHAVIOR, RISK REDUCTION) OR (BEHAVIORS, RISK REDUCTION) OR (LIFESTYLE RISK REDUCTION) OR (LIFESTYLE RISK REDUCTIONS) OR (RISK REDUCTIONS) OR (RISK REDUCING BEHAVIOR) ) OR ((RISK REDUCING BEHAVIOUR) OR (RISK REDUCING BEHAVIORS) OR (RISK REDUCING BEHABVIOURS) OR (SEXUAL RISK BEHAVIOR) OR (SEXUAL RISK BEHAVIOUR) OR (SEXUAL RISK BEHAVIORS) OR (SEXUAL RISK BEHAVIOURS) OR (SEXUAL RISK REDUCTION))

\#2

Search: (randomised controlled trial OR controlled 3002284 clinical trial OR randomised OR placebo OR drug therapy OR randomly OR trial OR groups) NOT (animals 
$[\mathrm{mh}]$ NOT humans $[\mathrm{mh}])$

\begin{tabular}{|c|c|c|}
\hline$\# 1$ & $\begin{array}{l}\text { Search: ("HIV Infections"[MeSH] OR "HIV" }[\mathrm{MeSH}] \\
\text { OR hiv [tw] OR hiv-1*[tw] OR hiv-2*[tw] OR hiv1[tw] } \\
\text { OR hiv2[tw] OR hiv infect*[tw] OR human immun- } \\
\text { odeficiency virus[tw] OR human immunedeficiency } \\
\text { virus[tw] OR human immuno-deficiency virus[tw] OR } \\
\text { human immune-deficiency virus[tw]) OR (((human } \\
\text { immun*) AND (deficiency virus[tw])) OR acquired im- } \\
\text { munodeficiency syndrome[tw] OR acquired immuned- } \\
\text { eficiency syndrome[tw] OR acquired immuno-defi- } \\
\text { ciency syndrome[tw] OR acquired immune-deficiency } \\
\text { syndrome[tw] OR ((acquired immun*) AND (defi- } \\
\text { ciency syndrome[tw])) OR "Sexually Transmitted Dis- } \\
\text { eases, Viral“[MeSH:NoExp]) }\end{array}$ & 367397 \\
\hline
\end{tabular}

Appendix 5. Pubmed search strategy

Database:

PubMed 1980 - 2008

Date:

18 July 2008

\begin{tabular}{|c|c|c|c|}
\hline Search & Most Recent Queries & Time & Result \\
\hline \#14 & $\begin{array}{l}\text { Search \#9 AND \# } 12 \text { Limits: Publication } \\
\text { Date from } 1980 \text { to } 2008\end{array}$ & 10:05:50 & 128 \\
\hline \#13 & Search \#9 AND \#12 & $09: 31: 25$ & 128 \\
\hline \#12 & $\begin{array}{l}\text { Search (HOMELESS YOUTHS) OR } \\
\text { (YOUTH, } \\
\text { LESS) OR (YOUTHS, HOMELESS) } \\
\text { OR } \\
\text { CHILD) OR (CHILD, HOMELESS) } \\
\text { OR (HOMELESS CHILDREN) OR } \\
\text { (CHILDREN, } \\
\text { LESS) OR (STREET YOUTH) OR } \\
\text { (YOUTH, STREET) OR (YOUTHS, } \\
\text { STREET) OR RUNAWAYS ORRUN- } \\
\text { AWAY OR (STREET CHILDREN) } \\
\text { OR (CHILDREN, STREET) OR } \\
\text { (STREET CHILD) OR (CHILD, } \\
\text { STREET) }\end{array}$ & 09:29:22 & 13385 \\
\hline
\end{tabular}




\begin{tabular}{|c|c|c|c|}
\hline \#9 & Search \#6 AND \#7 AND \#8 & 09:04:23 & 7211 \\
\hline$\# 8$ & $\begin{array}{l}\text { Search (RISK REDUCTION BEHAV- } \\
\text { IOR) OR (RISK REDUCTION BE- } \\
\text { HAVIORS) OR (RISK REDUCTION } \\
\text { BEHAVIOUR) OR (RISK REDUC- } \\
\text { TION BEHAVIOURS) OR (BEHAV- } \\
\text { IOR, RISK REDUCTION) OR (BE- } \\
\text { HAVIORS, RISK REDUCTION) OR } \\
\text { (LIFESTYLE RISK REDUCTION) } \\
\text { OR (LIFESTYLE RISK REDUC- } \\
\text { TIONS) OR (RISK REDUCTIONS) } \\
\text { OR (RISK REDUCING BEHAV- } \\
\text { IOR) OR (RISK REDUCING BE- } \\
\text { HAVIOUR) OR (RISK REDUCING } \\
\text { BEHAVIORS) OR (RISK REDUC- } \\
\text { ING BEHABVIOURS) OR (SEX- } \\
\text { UAL RISK BEHAVIOR) OR (SEX- } \\
\text { UAL RISK BEHAVIOUR) OR (SEX- } \\
\text { UAL RISK BEHAVIORS) OR (SEX- } \\
\text { UAL RISK BEHAVIOURS) OR (SEX- } \\
\text { UAL RISK REDUCTION) }\end{array}$ & 09:03:57 & 50877 \\
\hline \#7 & $\begin{array}{l}\text { Search randomised controlled trial [pt] } \\
\text { OR controlled clinical trial [pt] OR ran- } \\
\text { domised controlled trials [mh] OR ran- } \\
\text { dom allocation [mh] OR double-blind } \\
\text { method [mh] OR single-blind method } \\
\text { [mh] OR clinical trial [pt] OR clini- } \\
\text { cal trials [mh] OR ("clinical trial“ [tw]) } \\
\text { OR ((singl* [tw] OR doubl* [tw] OR } \\
\text { trebl* [tw] OR tripl* [tw]) AND (mask* } \\
\text { [tw] OR blind* [tw])) OR ( placebos } \\
\text { [mh] OR placebo* [tw] OR random* } \\
\text { [tw] OR research design [mh:noexp] } \\
\text { OR comparative study [mh] OR evalua- } \\
\text { tion studies [mh] OR follow-up studies } \\
\text { [mh] OR prospective studies [mh] OR } \\
\text { control* [tw] OR prospectiv* [tw] OR } \\
\text { volunteer* [tw]) NOT (animals [mh] } \\
\text { NOT human [mh]) }\end{array}$ & 08:59:50 & 2915070 \\
\hline \#6 & $\begin{array}{l}\text { Search (HIV Infections[MeSH] OR } \\
\text { HIV[MeSH] } \\
\text { OR hiv[tw] OR hiv- } 1^{*}[\mathrm{tw}] \text { OR hiv- } \\
2^{*}[\mathrm{tw}] \text { OR hiv1[tw] OR hiv2[tw] OR } \\
\text { hiv infect*[tw] OR human immun- } \\
\text { odeficiency virus[tw] OR human im- } \\
\text { munedeficiency virus[tw] OR human }\end{array}$ & $08: 59: 28$ & 233249 \\
\hline
\end{tabular}


immuno-deficiency virus[tw] OR human immune-deficiency virus[tw] OR ((human immun*) AND (deficiency virus[tw])) OR acquired immunodeficiency syndrome[tw] OR acquired immunedeficiency syndrome[tw] OR acquired immunodeficiency syndrome[tw] OR acquired immune-deficiency syndrome[tw] OR ((acquired immun*) AND (deficiency syndrome $[\mathrm{tw}]))$ OR "sexually transmitted diseases, viral“[MESH:noexp])

Database:

PubMed 2008 - 2010

Date:

13 January 2010

\begin{tabular}{|c|c|c|c|}
\hline Search & Most Recent Queries & Time & Result \\
\hline$\# 7$ & $\begin{array}{l}\text { Search ("2008/07/01“[Pub- } \\
\text { lication Date] : "2010/01/13“[Publi- } \\
\text { cation Date]) AND (\#4 AND \#5) }\end{array}$ & 07:21:07 & 7 \\
\hline \#6 & Search \#4 AND \#5 & $07: 19: 56$ & 53 \\
\hline$\# 5$ & $\begin{array}{l}\text { Search (HOMELESS YOUTHS) OR } \\
\text { (YOUTH, } \\
\text { LESS) OR (YOUTHS, HOMELESS) } \\
\text { OR } \\
\text { CHILD) OR (CHILD, HOMELESS) } \\
\text { OR (HOMELESS CHILDREN) OR } \\
\text { (CHILDREN, HOMELESS) OR } \\
\text { (STREET YOUTH) OR (YOUTH, } \\
\text { STREET) OR (YOUTHS, STREET) } \\
\text { OR RUNAWAYS OR RUNAWAY OR } \\
\text { (STREET CHILDREN) OR (CHIL- } \\
\text { DREN, STREET) OR (STREET } \\
\text { CHILD) OR (CHILD, STREET) }\end{array}$ & 07:19:32 & 15584 \\
\hline \#4 & Search \#1 AND \#2 AND \#3 & $07: 19: 14$ & 3556 \\
\hline$\# 3$ & $\begin{array}{l}\text { Search (RISK REDUCTION BE- } \\
\text { HAVIOR) OR (RISK REDUCTION }\end{array}$ & $07: 18: 52$ & 62464 \\
\hline
\end{tabular}


BEHAVIORS) OR (RISK REDUCTION BEHAVIOUR) OR (RISK REDUCTION BEHAVIOURS) OR (BEHAVIOR, RISK REDUCTION) OR (BEHAVIORS, RISK REDUCTION) OR (LIFESTYLE RISK REDUCTION) OR (LIFESTYLE RISK RE-

DUCTIONS) OR (RISK REDUCTIONS) OR (RISK REDUCING BEHAVIOR) OR (RISK REDUCING BEHAVIOUR) OR (RISK REDUCING BEHAVIORS) OR (RISK REDUCING BEHABVIOURS) OR (SEXUAL RISK BEHAVIOR) OR (SEXUAL RISK BEHAVIOUR) OR (SEXUAL RISK BEHAVIORS) OR (SEXUAL RISK BEHAVIOURS) OR (SEXUAL RISK REDUCTION)

\#2 Search (randomised controlled trial 07:18:12 2192606 [pt] OR controlled clinical trial [pt] OR randomised [tiab] OR placebo [tiab] OR drug therapy [sh] OR randomly [tiab] OR trial [tiab] OR groups [tiab]) NOT (animals [mh] NOT humans [mh])

\#1 Search (HIV Infections[MeSH] OR 07:17:36 253047 HIV[MeSH] OR hiv[tw] OR hiv$1^{*}[\mathrm{tw}]$ OR hiv-2*[tw] OR hiv1[tw] OR hiv2[tw] OR hiv infect*[tw] OR human immunodeficiency virus[tw] OR human immunedeficiency virus[tw] OR human immuno-deficiency virus $[\mathrm{tw}]$ OR human immunedeficiency virus $[\mathrm{tw}]$ OR ((human immun*) AND (deficiency virus[tw])) OR acquired immunodeficiency syndrome[tw] OR acquired immunedeficiency syndrome[tw] OR acquired immuno-deficiency syndrome[tw] OR acquired immune-deficiency syndrome[tw] OR ((acquired immun*) AND (deficiency syndrome[tw])) OR "sexually transmitted diseases, viral“[MESH:noexp]) 


\section{Appendix 6. Psycinfo search strategy}

\section{Database: $\quad$ Psycinfo}

Date: $\quad 09$ February 2010

$\mathrm{KW}=$ keywords $=$ terms from title, abstract or descriptors

Earliest to 2010

Peer-reviewed articles

No restrictions on language

$\mathrm{KW}=\left(\right.$ homeless or runaway or vagran* or $\left(\right.$ street chil $\left.\left.^{*}\right)\right)$ AND KW=(youth or adolesce* or teen* or (young people) or (young adult $\left.{ }^{*}\right)$ ) AND KW $=(($ human immun*) or risk* or HIV or (HIV/AIDS) or (acquired immun*) or (sexually transmitted) or STD or STI) AND $\mathrm{KW}=\left(\right.$ randomi* $^{*}$ or RCT or trial $\left.{ }^{*}\right)$ AND KW=prevent* and NOT KW=(perinatal* or MTCT or mother-to-child)

\section{Appendix 7. LILACS search strategy}

Database: LILACS

Date: 21 July 2010

Acquired Immunodeficiency Syndrome OR Sindrome de Inmunodeficiencia Adquirida OR Sindrome de Imunodeficincia Adquirida OR HIV infections OR Infecciones por VIH OR Infeces por HIV OR HIV OR VIH OR HIV-1 OR VIH-1 OR HIV2 OR VIH-2 OR HIVIAIDS OR SIDA

\section{AND}

Homeless Youth OR Jovenes sin Hogar OR Menores de Rua OR homeless children OR street youth OR street children OR homeless persons OR Personas sin Hogar OR Sem-Teto OR street people OR homeless

\section{H IS T O R Y}

Protocol first published: Issue 4, 2008

Review first published: Issue 1, 2011

\begin{tabular}{|c|c|c|}
\hline Date & Event & Description \\
\hline 7 February 2008 & New citation required and major changes & Substantive amendment \\
\hline
\end{tabular}

\section{CONTRIBUTIONSOFAUTHORS}

$\mathrm{VN}$ designed and coordinated the conduct of this review.

$\mathrm{VN}$ and AM performed the data collection, abstraction and entry for the review with the assistance of the South African Cochrane centre and were responsible for the writing of this review.

QAK and NS secured funding for the review, provided general advice for the review and a methodological perspective, and critically read and appraised the final review. 


\section{DECLARATIONS OF INTEREST}

None.

\section{SOURCES OFSUPPORT}

\section{Internal sources}

- Center for the AIDS Program of Research In South Africa, South Africa.

- HIV/AIDS Mentoring Programme, South African Cochrane Centre, South Africa.

\section{External sources}

- LIFELab Merit scholarship, South Africa.

Vivek Naranbhai was supported by a LIFELab Merit award, 2009-10

- Columbia University-Southern African Fogarty AIDS International Training and Research Program (AITRP) funded by the Fogarty International Center, National Institutes of Health, South Africa.

Vivek Naranbhai was supported by the CU-SA Fogarty AITRP, (grant \# D43TW00231), 2007-9.

- National Institute of Allergy and infectious Disease (NIAID), National Institutes of Health, Not specified.

Financial support for CAPRISA from NIAID/NIH (grant\# AI51794) is gratefully acknowledged.

\section{DIFFERENCES BETWEEN PROTOCOLANDREVIEW}

We modified the age of participants for eligible trials from 15-24 years(inclusive) to 12-24 years (inclusive).

\section{N DEX TERMS}

\section{Medical Subject Headings (MeSH)}

${ }^{*}$ Homeless Youth; ${ }^{\text {Risk-Taking; }}{ }^{*}$ Sexual Behavior; Adolescent; HIV Infections [ ${ }^{*}$ prevention \& control]; Randomized Controlled Trials as Topic; Substance-Related Disorders [complications]

\section{MeSH check words}

Female; Humans; Male; Young Adult 